\title{
MOULDS FOR LARGE DAGGERS. UNIQUE FINDS FROM THE BRONZE AGE HATVAN-STRÁZSA-HEGY TELL
}

\author{
JÁNOS GÁBOR TARBAY \\ Department of Archaeology, Prehistoric Collection of the Hungarian National Museum \\ 14-16 Múzeum krt, H-1088 Budapest, Hungary \\ tarbay.gabor@mnm.hu
}

This article is dedicated to the memory of Dr. Tibor Kovács, the former director of the Hungarian National Museum,

a pioneering prehistorian,

whose life-work is an inspiration for future research.

\begin{abstract}
The present study discusses five Bronze Age sandstone casting moulds from the Hatvan-Strázsa-hegy tell (Hungary, Heves County), which have been acquired by the Ministry of Defence Institute and Museum of Military History in the 1990s. One of the moulds is a semi-finished product, showing a negative of a dagger hilt pommel. The other four moulds were suitable to cast large triangular-shaped dagger blades and they can be arranged into two pairs, based on their dimensions and the outlines of their negatives. According to macroscopic observations, these finds have been used for a period of time, proving that advanced metallurgy was present on the Strázsa-hegy site during the Rei. Br. A. Besides they provide a chance for an evaluation of these significant objects that do not abound in parallels. The main goal of this paper is to discuss and reconstruct the life-cycle of daggers, based on macroscopic data obtained from the moulds and their parallel finds.
\end{abstract}

Keywords: casting moulds, daggers, Bronze Age (Rei. Br. A), use-wear, object's biography

\section{INTRODUCTION}

The Ministry of Defence Institute and Museum of Military History (MoD IMMH) has a significant collection of prehistoric artefacts from the Neolithic up on to the Iron Age. This article is part of a project, which aims to publish the most important finds of this collection, before then release of a complete scientific catalogue. After the study on the Late Bronze Age warrior's equipment, ${ }^{1}$ hereby I pick up the thread and present another set of prominent finds, five Bronze Age dagger casting moulds. The objects were recovered by a local historian, András Kassa. According to his statement, he found them when he walked on the northwestern part of the Hatvan-Strázsa-hegy tell (Hungary, Heves County), "3-5 meters to south-west from the highest point" (Fig. 1). The objects were on the surface, at the edge of a pit, along with a large piece of daub, thrown away by a local resident, who intended to plant a fruit tree there. Thus, the exact context of these moulds was destroyed by the earthwork. They may have been either part of a hoard deposited in a settlement object or put in a pit along with the debris. However, the close typological and technological relations, as well as the fact that four of them belonged together as pairs, strongly implies that these finds should be treated as one assemblage.

After the accidental finding by András Kassa, the moulds have been acquired by the MoD IMMH, and they were inventoried in 1994, as unprovenanced finds. Some of the objects were published in 1996 by Gábor Németi, the director of the Hatvany Lajos Múzeum at that time, in his paper titled as Hatvan lakói a honfoglalás elött [The Inhabitants of Hatvan before the Hungarian Conquest]. Here G. Németi used A. Kassa's own black-and-white, lowresolution photographs and presented the finds without evaluation, and mentioned the "M3 motorway" as their place

${ }^{1}$ TARBAY 2015. 

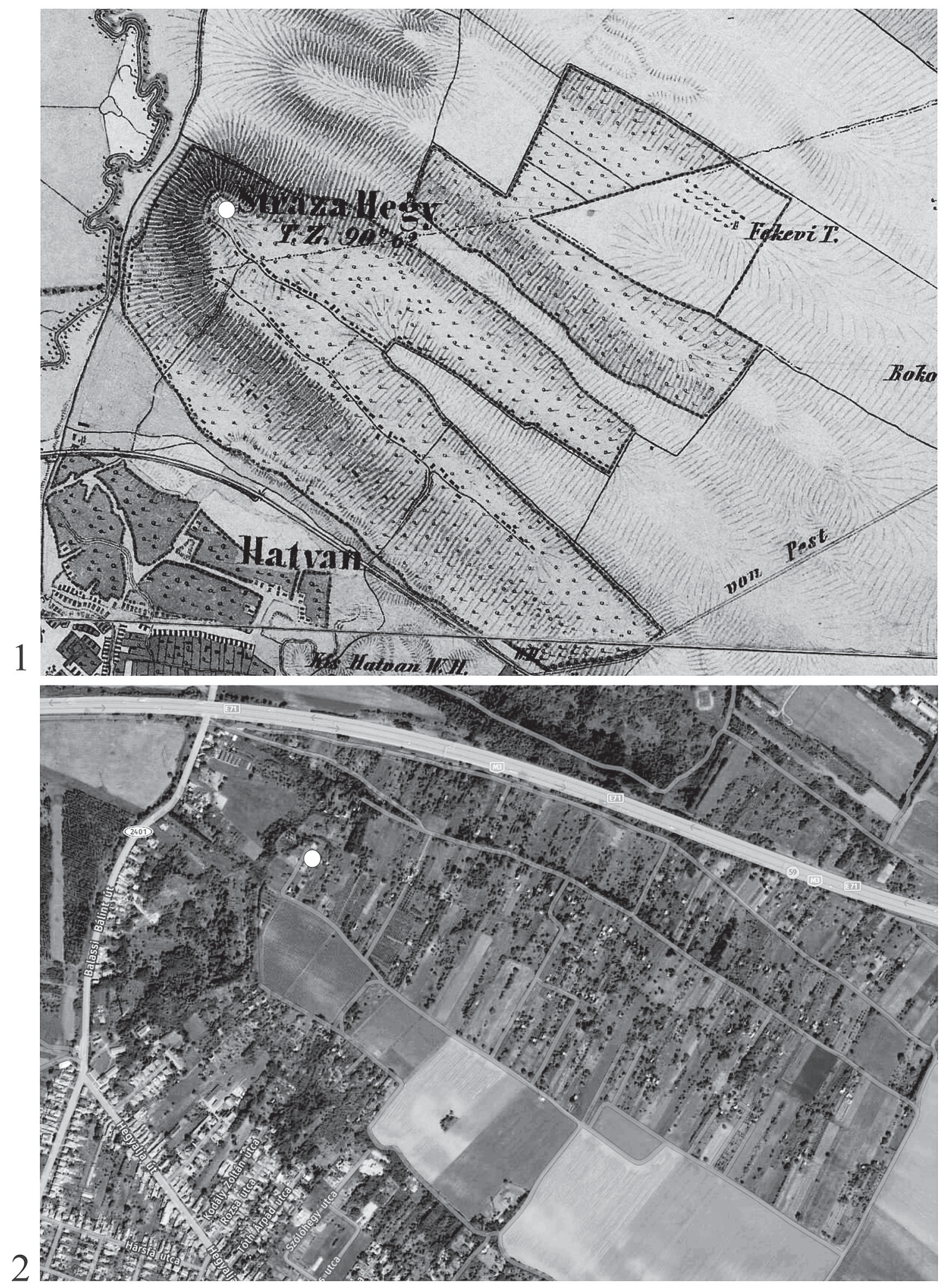

Fig. 1. The Hatvan-Strázsa-hegy and the find-spot of the moulds.

1: Second Military Survey of the Habsburg Empire; 2: Present-day satellite map 
of provenance. ${ }^{2}$ In 2017, I had the pleasure of meeting A. Kassa on the occasion of a new Late Bronze Age metal stray find from Hatvan. Having an enlightening discussion with him on the Bronze Age metallurgy from the vicinity of Hatvan, we have quickly came to the conclusion that the unprovenanced dagger moulds in the MoD IMMH are identical with the moulds that he had found in the Hatvan-Strázsa-hegy years before (Fig. 2, Fig. 4-9). Thanks to this coincidence, it was finally possible to carry out a more precise analysis on these finds, in context of their exact provenance.

Within this study, the five mould pieces will be published in details and investigated from a technological and typological point of view. In addition to the evaluation of these significant artefacts, the study will focus on the reconstruction of the moulds' and daggers' biography and life-cycles, based on macroscopic data obtained from the moulds from Hatvan-Strázsa-hegy and their parallel finds.

\section{THE HATVAN-STRÁZSA-HEGY TELL}

The Strázsa-hegy is situated in the Northeastern part of present day Hatvan city (Heves County), 175 meters above sea level (Fig. 1). ${ }^{3}$ One of the earliest mention of this Early and Middle Bronze Age site can be found in the 1864 work of Flóris Rómer, who listed "several serpentine stones axes", ceramic sherds and a hollow pyramidlike clay object, based on the report of Mr. Varsányi. ${ }^{4}$ In 1876, József Sperlágh excavated several sites in the surroundings of Hatvan, one of them was the Strázsa-hegy tell, where he spent four days between 2 and 5 of August 1876. J. Sperlágh only carried out a field survey with eight workers as excavating was not allowed in the vineyards. This survey resulted minor finds, among them different types of stone tools, a "bronze arrowhead" (dagger), a conical-shaped clay object and ceramic sherds can be mentioned. ${ }^{5}$ On 29 August 1876, he donated a handful of artefacts to the Hungarian National Museum (HNM). The description of these objects in the inventory book of the HNM seems to correlate with Sperlágh's report, although only "Hatvan" was recorded as place of provenance. ${ }^{6}$ József Hampel, and also Ferenc Tompa mentioned that an urn cemetery was excavated by J. Sperlágh on the Strázsahegy, whose material has been donated to the HNM along with a knobbed sickle and a socketed chisel without loop. ${ }^{7}$ These finds were inventoried in the HNM on 27 December 1876. However, the information in the publications and the inventory book are controversial, and it is not entirely clear whether finds from the Strázsa-hegy can be interpreted as grave goods of a cemetery. ${ }^{8}$

The years 1934 and 1935 were significant in the research of the Strázsa-hegy site. In these years, F. Tompa carried out his excavations, which were published in the 'Archaeologiai Értesítö', under the title of Bronzkori

\footnotetext{
${ }^{2}$ NÉMETI 1996, Fig. 4. The M3 motorway runs next to the northern part of the Strázsa-hegy. According to A. Kassa, G. Németi noted incorrectly the site's topographical position.

${ }^{3}$ NovÁKi et al. 2009, 94.

${ }^{4}$ RÓMER 1864, 166, No. 726.

${ }^{5}$ HensZlmann 1876, 248; SPERLÁGH 1877, 58-60; RÓMER 1877a, 217; RÓMER 1877b, 60-61; TOMPA 1935, 16; HORVÁtH 1998, Abb. 91,1; KALICZ 1968, 120-121.

${ }^{6}$ SPERLÁGH 1877, 60. The artefacts are the following: 1. stone axe (1876.187.1), 2. obsidian flint (1876.187.2), 3. oval-shaped stone tool (1876.187.3) 4. two ceramic discs (spindle whorls) and a bone pendant (Inv. No. 1876.4), 5. triangular-shaped, small bronze dagger, described as an "arrowhead" (Inv. No. 1876.187.5), 6. bone pendant (Inv. No. 1876.187.6). The $1^{\text {st }}, 3^{\text {rd }}$ and $6^{\text {th }}$ items cannot be found currently in the collection of the HNM Inv. No. 1876.187.1-6. J. Sperlágh also mentioned several ceramic finds, which he has discarded after collecting them on the site. According to him, these finds were re-collected by the repesentatives of the Prehistoric Congress on their excursion. SPERLÁgh 1877, 60. On 30 December 1876 several finds had been donated to the HNM under the provenance of Hatvan, by the participants of the first excursion of the Prehistoric Congress (Inv. No. 1876.309.1-704). Some of these could have been originating from Sperlágh's field survey. HNM Inv. No. 1876.309.1-704.
}

${ }^{7}$ Hampel 1880, 49-60, Taf. VII.3a-c; Hampel 1886, Taf. LXXXVIII.3a-c; HAMPEL 1892, 58; TOMPA 1935, 16. These finds could not be identified in the collection in 2018 .

${ }^{8}$ From the Strázsa-hegy 4 antler tools and 18 ceramic vessels were inventoried in one entry (Inv. No. 1876.298.2-24). The knobbed sickle and the socketed chisel were inventoried under different numbers (Inv. No. 1876.298.42, Inv. No. 1876.298.44), suggesting that they do not belong to the above finds. There are no comments which indicate that these artefacts would originate from a cemetery. Only one object has been described as an "urn-like pot" (Inv. No. 1876.298.17). The next items in the collection are originating from the Hatvan-Kálvária domb site (Inv. No. 1876.298.24-41). In his report, Sperlágh mentions an excavated cemetery from the site mentioned above. SPERLÁGH 1877, 58. In the case of the Kálvária domb finds, the inventory book clearly describes the urns' function, i.e. had contained cremated remains (e.g. Inv. Nos. 1876.298.24-26). It seems plausible that J. Hampel exchanged the stray finds from Hatvan-Strázsa-hegy with the material of the Kálvária domb cemetery. In addition to the finds acquired by the HNM, there are also references in the publications of objects from the Hatvan-Strázsa-hegy that were kept in the collections of J. Sperlágh and József Révész. See RóMER 1877b, 60 61; TOMPA 1935, 16. 
lakótelep Hatvanban [A Bronze Age settlement in Hatvan]. ${ }^{9}$ As a result of his work, this tell became the eponymous site of the Hatvan pottery style, which is a cultural complex that covers the northeastern part of the Carpathian Basin, especially the territory of the North Hungarian Mountains and the region of the Tisza and Korrös rivers, between the Early (EBA III) and Middle Bronze Age (MBA I). ${ }^{10}$ According to F. Tompa, his sections covered $590 \mathrm{~m}^{2}$ in total, and the excavated tell consisted of three layers. ${ }^{11}$ The upper layer (No 1) was disturbed by ploughing and contained many ceramic finds in secondary position, as well as traces of a heavily burnt floor and only a few postholes. ${ }^{12} \mathrm{~F}$. Tompa had excavated four houses with massive burnt clay floors in their middle layers (No. 2) and also four houses with a length of 20 meters along their lowest layers. ${ }^{13}$ The section of the houses' floors showed debris, multiple burnt and renewal layers, which were interpreted by the excavator as the result of cyclic intentional burning and re-building of the houses within the settlement, mostly for hygienic purposes. ${ }^{14}$ Most of the excavated finds were yellowish brown, light grey household pottery, e.g. pots, bowls, storage vessels with characteristic brushed, impressed and gadrooned decorations. ${ }^{15}$ Iconic finds were the miniature vessels, the animal figures and small clay hammers imitating real-size stone tools. ${ }^{16}$ Special ceramic types were also present, for instance a larger vessel with incised decoration and inner knobs, that most likely served as souring pot according to F. Tompa. ${ }^{17}$ Fine ceramics such as bowls and cups were also excavated, which can be characterized by bright surface, fine tempering and black, blackish grey colour. ${ }^{18}$ Also typical stone, bone and other ceramic artefacts were found, which have many parallels from contemporary settlements. ${ }^{19}$ Similarly to the tells of the Hatvan pottery style,$^{20}$ finds related to metallurgy were extremely rare, only one bronze torques with rolled terminals and a sandstone casting mould of rod ingots were recovered from the site (Appendix, Catalogue, No. 4, Fig. 12.4, Fig. 13.4). ${ }^{21}$ The latter small open-mould is only an edge fragment of a larger one, which was used for producing at least three long, triangular-sectioned rod ingots. ${ }^{22}$ It showed also burnt traces similar to the dagger moulds found in the 1990s. The rod-ingot mould is an evident trace of metallurgical activity on the site, as it was used to hold the excess metal after casting, which solidified thereafter to a dividable shape. F. Tompa dated the settlement based on the fine ceramics, which he associated with the $3^{\text {rd }}$ Period of the Hungarian Bronze Age (Tószeg C, 1400-1200 BC). ${ }^{23}$ A new evaluation of the site and its cultural background was given by Nándor Kalicz in his seminal 1968 monograph.$^{24}$ The Strázsa-hegy tell's chronological position was modified later, as the upper level of the settlement was in parallel with the early stage of the Füzesabony culture, making the whole chronological period of the site between EBA IIa-MBA I. ${ }^{25}$

On the Strázsa-hegy, new field works have been carried out in 1970s. In 1977, the local brick factory started clay extraction on the site. János Győző Szabó's rescue excavation was only able to salvage a few remaining objects. According to his report, burials were dated to the pre-Scythian Period, while the excavated pits contained artefacts characteristic to the Hatvan pottery style. ${ }^{26}$ Three more field surveys were noted in the literature, one of them was carried out by Gyula Nováki between 18 April 1993 and 25 August 2008, another one between 19 and 29 February 2001 by István Paszternák és Adél Váradi. All field surveys resulted in several ceramic finds, but found no traces of fortifications. ${ }^{27}$

${ }^{9}$ Tомра 1935; TомРA 1937, 86, Abb. 6, Taf. 30.11-13, 15-17, Taf. 31.22-25; KALICZ 1984, 192.

${ }^{10}$ KaLICZ 1968, 114-134, Abb. 4; NEŠPOROVA 1969, 361382, Obr. 1; KALICZ 1984, 191-193; FURMÁNEK-VELIAČIK-VLADÁR 1991, 71-73; Bóna 1992a, 23; Guba 2016, 88-89, Fig. 1; Dani 2001, 139, map 5.2.

${ }^{11}$ No. 1: Upper layer $(20-30 \mathrm{~cm})$, No. 2: Middle layer (50-70 cm), No. 3: Lowest layer (110-150 cm). TomPA 1935, 17-20.

${ }^{12}$ Tompa $1935,17-18$.

${ }^{13}$ TOMPA 1935, 18-20, Abb. 13, Abb. 16

${ }^{14}$ Tompa 1935, 19-24. House burning in tell can also the result of intentional ritual acts, as the events of house burning were connected to the life-circle of the inhabitants. See SZEVERÉNYI 2013, 216-222.

\footnotetext{
${ }^{15}$ TOMPA 1935, 24-29.

${ }^{16}$ Tompa 1935, 28, 30, 32, Abb. 19.6-19.
}

${ }^{17}$ Tompa 1935, 28-29, Abb. 20-23.

${ }^{18}$ Tompa 1935, 29, 32, Abb. 19.1-5; TомPA 1937, 102.

${ }^{19}$ E.g. clay spoon, spinning whorl, clay funnel, perforated shell and pig tooth, stone axe and chisel, flint blades, bone awls, chisel, pins, antler tools etc. TOMPA 1935, 30-32.

${ }^{20}$ KaLicz 1968, 162-164.

${ }^{21}$ TOMPA 1935, 30, 32, Abb. 24.13-14.

${ }^{22}$ Ersfeld 1990, 11-13; Mozsolics 1984, 32-33; Armbruster 2000, 70; CZAJLIK 2012, 74.

${ }^{23}$ Tompa 1935, 29, 32, Abb. 19.1-5; Tompa 1937, 102.

${ }^{24}$ KaLicz 1968, 120-121, Nos 59-60.

${ }^{25}$ Mozsolics 1952, 53-54; KalicZ 1984, 192, 202; BÓNA 1992a, 23; NovÁKI et al. 2009, 94; GogÂltAn 2017, 47, Annexe 1, No. 63, Annexe 2, No. 63. Hatvan.

${ }^{26}$ SZABÓ 1977, 7.

${ }^{27}$ NovÁKI et al. 2009, 94. 


\section{USE-WEAR ANALYSIS OF THE MOULDS}

\subsection{Unfinished dagger hilt mould (Appendix, Catalogue No. 1)}

At first glance, Cat. No. 1 casting mould seems to be an odd artefact (Fig. 2). It bares all characteristics of a mould, but it has an irregular shape and its pouring cup is completely missing. The mould's front side is polished smoothly (Fig. 2.a).$^{28}$ In contrast, the polishing of the upper and lower parts are superficial (Fig. 2.e-f) and quite rough along the narrow sides and the backside (Fig. 2.b-d). In addition, the backside and one of the narrow sides shows clear traces of an edged tool in grazing light (Fig. 2.b-d, Fig. 3.1-3). According to experimental archaeo-

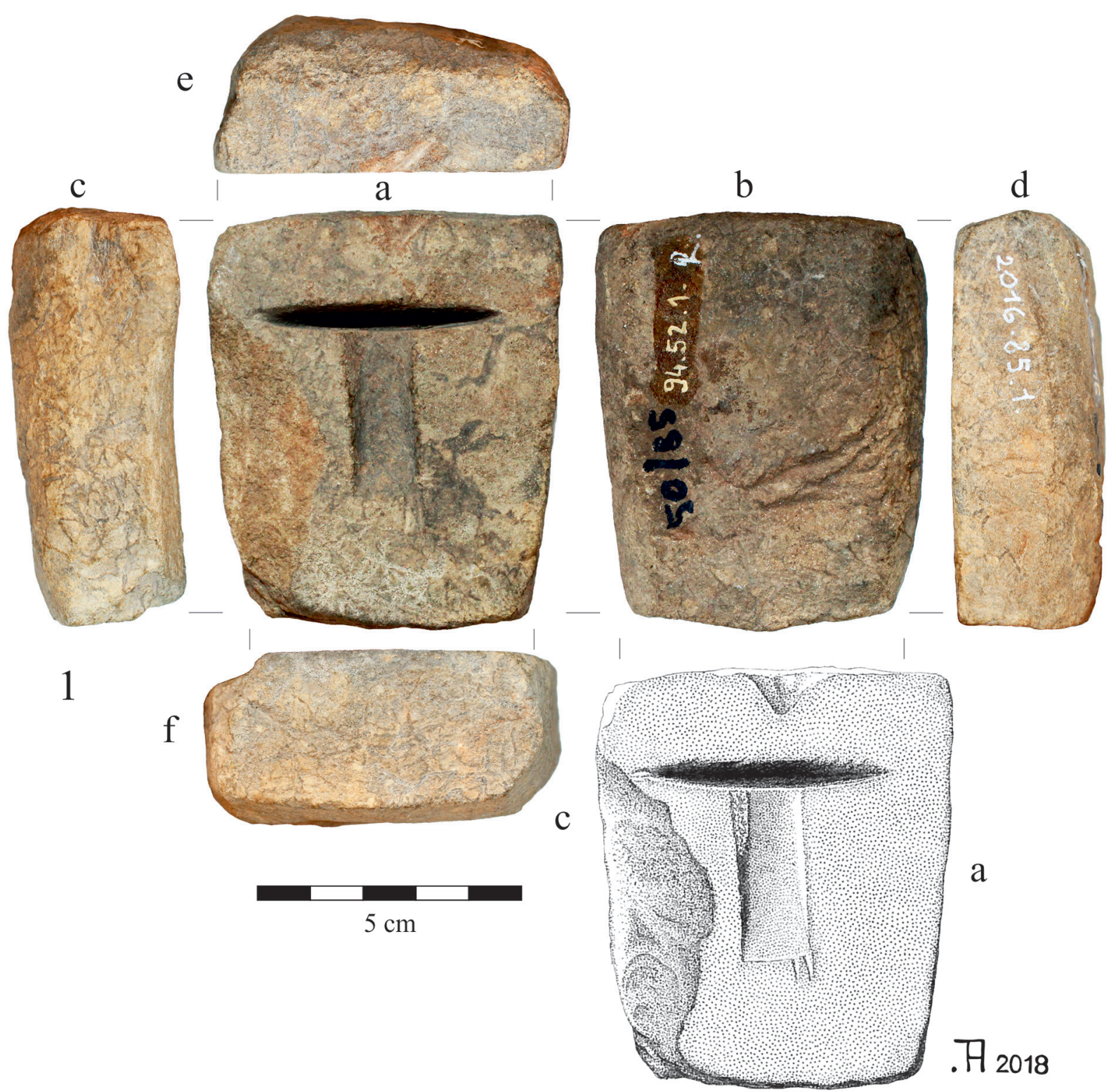

Fig. 2. Unfinished dagger hilt mould (Cat. No. 1) (MoD IMMH, Photos: J. G. Tarbay, Drawing: A. M. Tarbay)

${ }^{28}$ Polishing can be done by many different ways. As sandstone is composed of grate-sized mineral particles, it is possible that another sandstone or even a more resilient stone material was chosen for this process. 
logical research, such traces can be associated with metal chisels or chisel-like objects. ${ }^{29}$ In the case of EBA/MBA, narrow flat axes can be suitable candidates for such traces. These tools can be used in the early stage of the mould's production when the rectangular block is formed. Dimensions of the blade impact marks on the back side vary between ca. 13 and $19 \mathrm{~mm}$, and their shape implies that the tool had a rounded edge (Fig. 3.2). The impact marks are overlapping on the mould's sides, they run straight along the narrow side, and turn to the back side.

These observed phenomena suggest that this mould was probably unfinished. The maker of the mould only carved the negative of the discus-shaped pommel and part of the hilt, but the pouring cup and the lower part were not done. It is likely that these negatives were left unfinished because they are uncharacteristically too shallow. If a metal cast would have been done in this mould it would have had an uncharacteristic form compared to all known Carpathian and Western European EBA/MBA metal pommels (see Fig. 11.4), which also supports the above conclusions. The fact that the negative was unfinished also excludes the possibility that it was used for producing models for lost-wax casting. ${ }^{30}$ In sum, all macroscopic traces of the find suggest that it can be interpreted as an unfinished dagger pommel mould.

\subsection{Bivalve dagger mould: Pair I (Appendix, Catalogue Nos 2.1-2.2)}

Two bivalve casting moulds made of sandstone, which belong together as one pair (Pair I) (Fig. 4-6). A long triangular-sectioned rib was carved into both of them, forming a pouring cup on the upper part of the object. These negatives are the most crucial part of the moulds' design. On one side they function similarly as the jet de coulé $e^{31}$ helping to fill the moulds' cavity completely with fluid metal. On the other hand, these ribs provided great stability for the relatively thick and long cast blade. ${ }^{32}$ There can be no doubt that the two halves belong together, as the dimensions of their dagger-shapes are similar and a small carved sign was placed on their bottom, for their precise fitting (Fig. 4.2.1f, 2.2f, Fig. 5.2.1.f, Fig. 6.2.2f). On the other hand, they are not completely identical. While the negative of the blade has been carved on Cat. No. 2.1 mould (Fig. 4.2.1a, Fig. 5.2.1a), no such negative can be identified on Cat. No. 2.2. Only a burnt dagger-shaped imprint with comparable dimensions is visible on it (Fig. 4.2.2a, Fig. 5.2.2.a). By the aid of the above design, one can minimize the time of mould manufacturing and also the negative effects of a mismatch defect. This mould design is hard to observe on the finished metal objects, because hammering and annealing of the blade can completely re-shape the cross-section of the raw casts. ${ }^{33}$ Differences can be seen on the material of the mould halves. Both were made of sandstone but Cat. No. 2.2 has a rougher porous surface, while that of Cat. No. 2.1 is much more smooth. There is also an important difference in the dimensions of the mould pair. Cat. No. 2.1 is thicker, therefore much more durable than the thinner Cat. No. 2.2. Sandstone moulds tend to break easily, when hot metal fills their cavity. The thinner the wall of the mould is, the easier it breaks, which can be well exemplified by the discussed mould halves (Fig. 6.2.2). When someone designs a bivalve mould, it is important to manufacture identical pieces regarding both the dimensions and the material of the moulds. In the case of Pair I mould, the differences in sandstone material and thickness can refer to two different causes. The mould maker wished to spare the stone raw material and the difference in dimensions rather reflect the dimensions of the raw material available. On the other hand, it is also possible that one of the halves was manufactured later as a replacement from a different sandstone material.

Contrary to the Cat. No. 1 mould, Pair I is a completely finished product. The surfaces of both halves are completely smooth, no tool marks can be observed on them. These bivalve moulds were used, as the blackish burnt traces suggest on their surface (Fig. 3.5, Fig. 2.2a, Fig. 10.1, 3). One question may arise how can one cast in such mould? The shapes of the moulds are irregular, their lower part is rounded, which does not allow them to stand upright on their own. This type of mould can only be used being dug into sand. A similar method has been presented by Neil Burridge during experimental LBA sword casting. ${ }^{34}$ Particularly interesting is the Cat. No. 2.2 mould half, the upper part of which was completely burnt out showing a blackish dagger shaped imprint where the metal contacted the stone and a reddish colour on places that were affected by the heat. The upper part of this half form is also blackish around the pouring cup. It is possible that too much bronze has been poured into the form and the excess

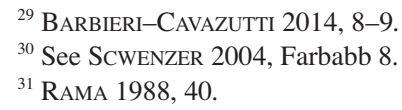

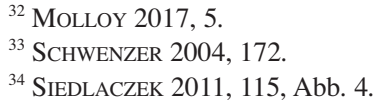



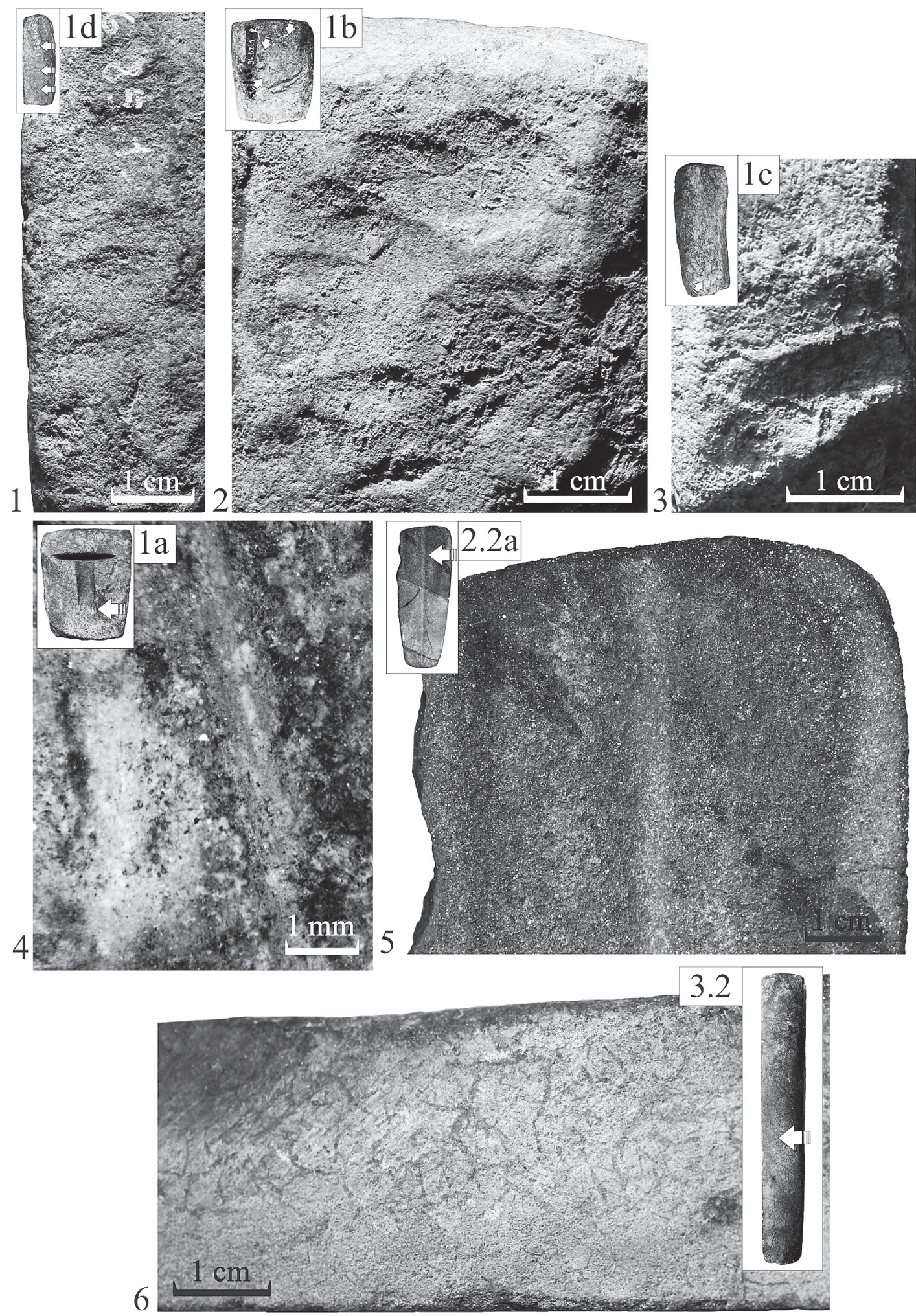

Fig. 3. Macroscopic observations. 1-3: Tool marks (Cat. No. 1); 4: Carving run out of the negative's outline (Cat. No. 1);

5: Dagger-shaped burnt imprint (Cat. No. 2.2); 6: Polishing traces (Cat. No. 3.2) (MoD IMMH, Photos\&Micrographs: J. G. Tarbay) 


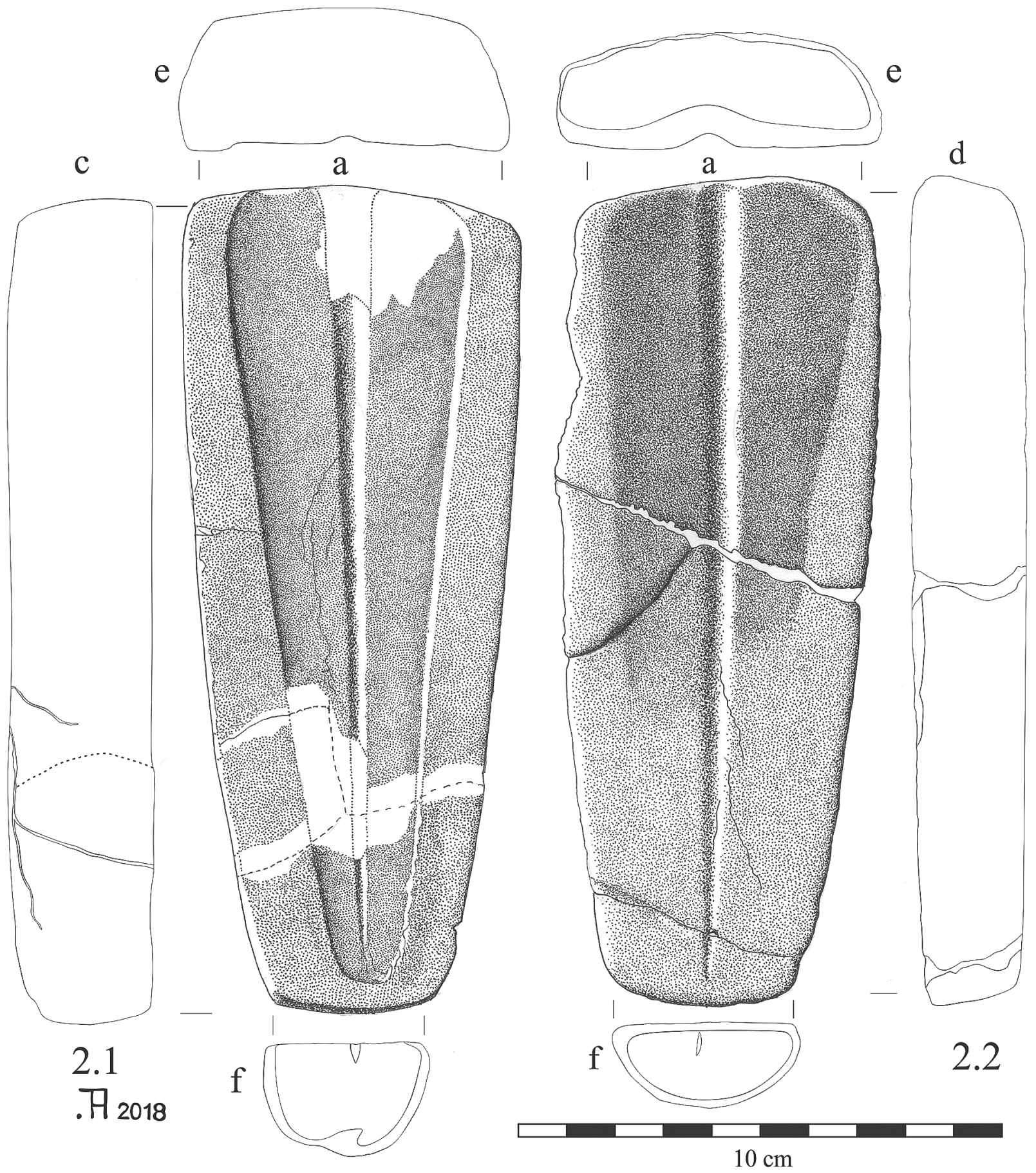

Fig. 4. Bivalve dagger mould, Pair I (Cat. Nos 2.1-2.2) (MoD IMMH, Drawings: A. M. Tarbay) 


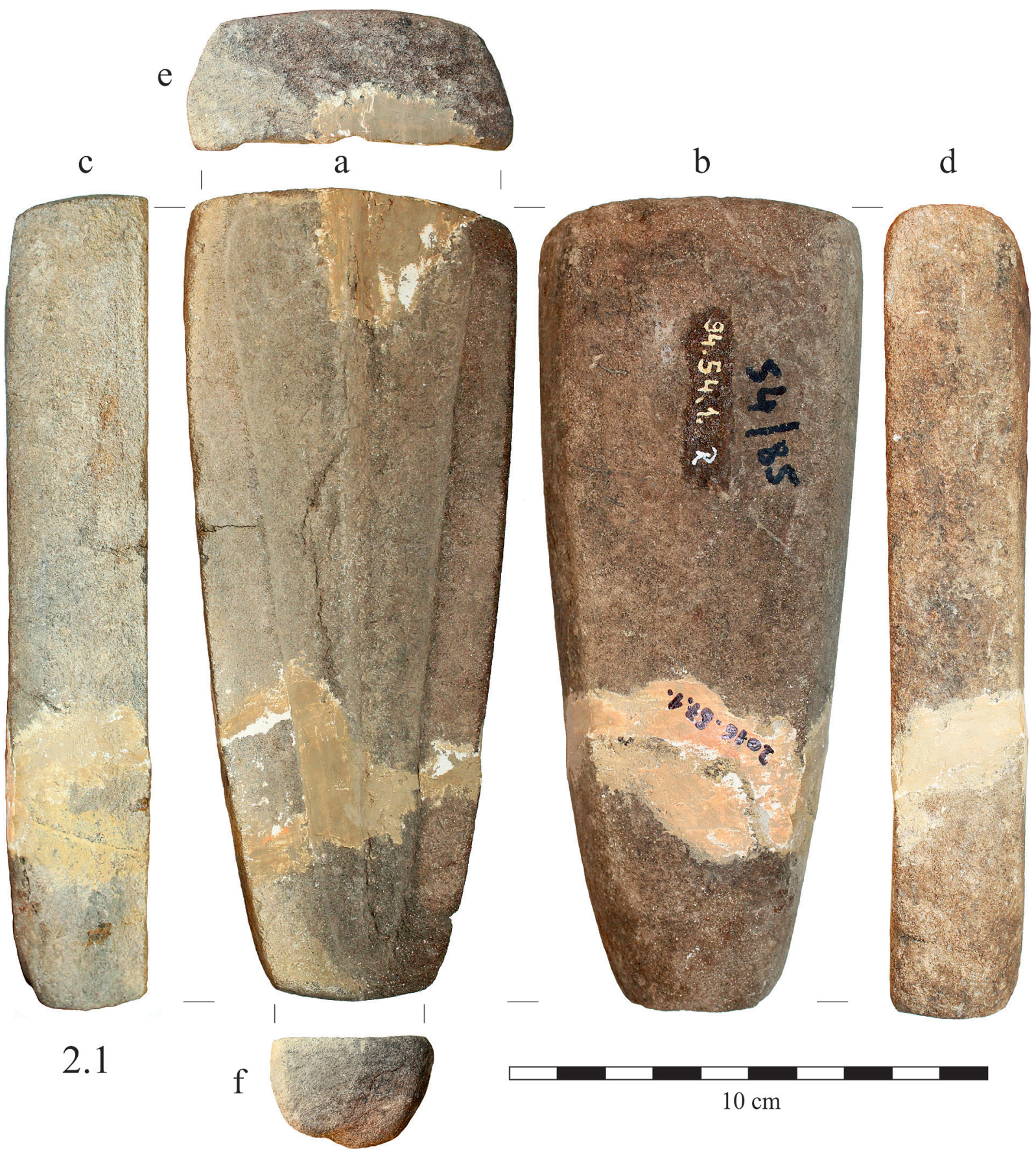

Fig. 5. Cat. No. 2.1 dagger mould (MoD IMMH, Photos: J. G. Tarbay) 


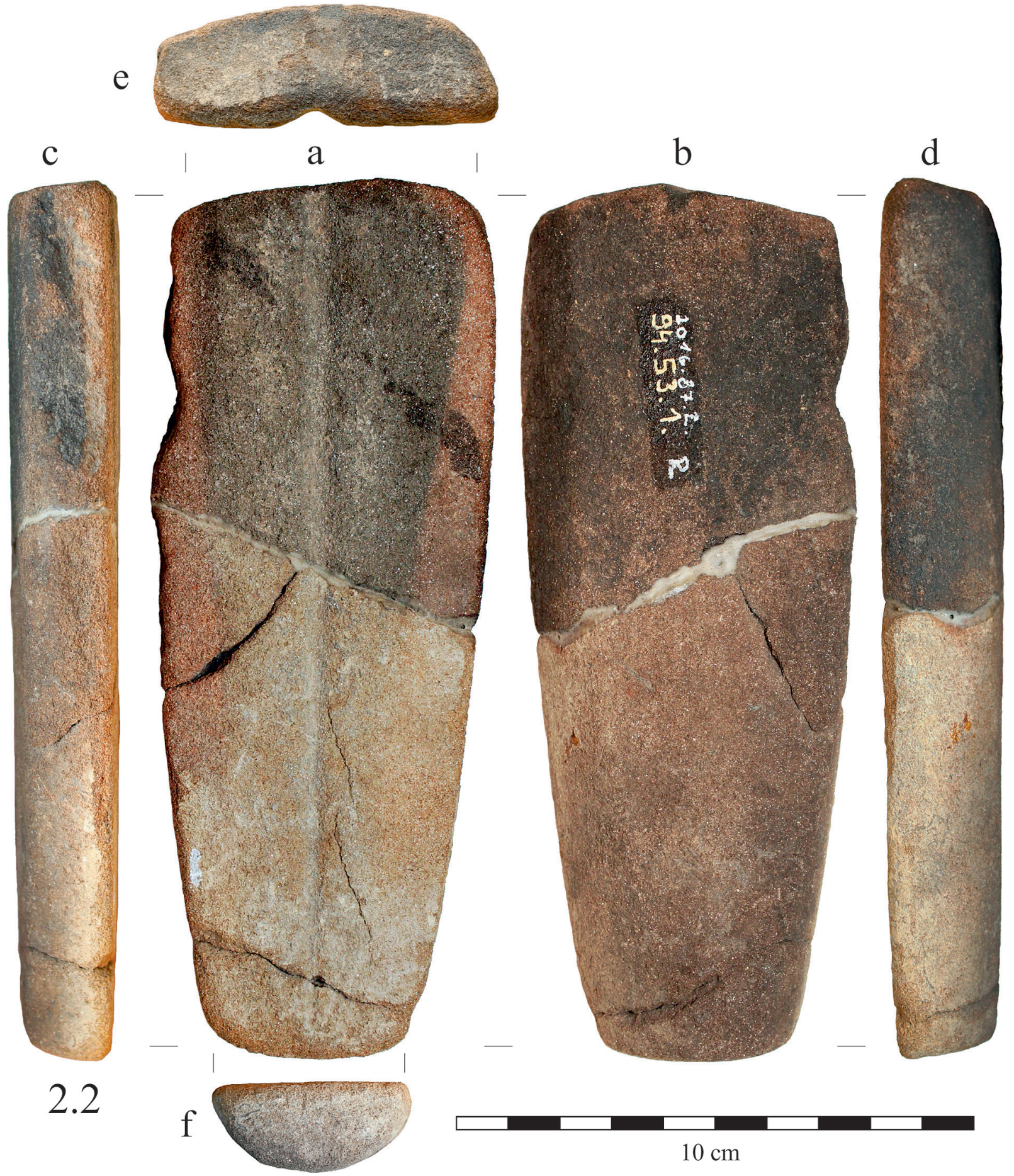

Fig. 6. Cat. No. 2.2 dagger mould (MoD IMMH, Photos: J. G. Tarbay) 
amount ran around. Horizontal and longitudinal cracks on Cat. No. 2.1 mould also can be interpreted as use-wear marks, caused by the hot metal.

\subsection{Bivalve dagger mould: Pair II (Appendix, Catalogue Nos 3.1-3.2)}

The design of Pair II casting mould (Fig. 7-9) is more or less similar to Pair I, but there are some major differences that should be emphasized here. Pair II is larger and the dimensions of the halves correlate with each other. The design of the negative follows the same concept, but in this case there is a pouring cup above the butt-end of the dagger's negative. ${ }^{35}$ Similar to Pair I, small carved signs are also visible on the bottom of the moulds (Fig. 7.3.1.f, 7.3.2.f, Fig. 8.3.1.f, Fig. 9.3.2.f). The exact shapes of the grooves are much more visible, showing a clear triangular cross-section. In mould making, such shape appears when the grooves are carved with an edged tool's tip. The surfaces of both moulds are smooth. On one mould (Cat. No. 3.2), sharp slanting polishing marks can be observed (Fig. 3.6) on one of its narrow sides. The other narrow side is concave (Fig. 9.3.2.b). Moulds can be polished using different methods: 1 . Polishing was carried out by a smaller object, which was pulled back and forth on the surface, 2. The mould was pulled back and forth on a larger polishing surface (e.g. flat stone). The phenomenon of concave narrow sides refer to the first option. On one of the narrow sides of the Cat. No. 3.2 mould, a long semi-circle sectioned groove can be seen (Fig. 7.3.2.c, Fig. 9.3.2.c). This can be interpreted as an additional negative of a rod ingot. ${ }^{36}$ In Pair II mould, multiple burnt imprints of daggers can be seen, one went beyond the outlines of the negative (Fig. 8.3.2a, Fig. 9.3.2.a, Fig. 10.4, Fig. 11.1-3). This phenomena suggest that at least two castings have been carried out by this mould pair and during these processes, the assembly of the moulds were different.

\subsection{Fragmentation}

The moulds showed traces of recent fragmentation, which could have been caused during the earthwork at the place of discovery. ${ }^{37}$ They also went through an amateur restoration, before arriving to the MoD IMMH. Cat. Nos 2-3. moulds have been supplemented by painted gypsum, which completely covers the broken surfaces and other part of the moulds. Some mould parts were even glued together (e.g. Cat. No. 1.2). The possibility should not be excluded that the breakages covered with glue or gypsum were results of prehistoric use. As a result of heat damage, sandstone casting moulds often broke into parts during the first or second casting phase. There are also longitudinal and horizontal cracks on some parts (Cat. No. 1.1), suggesting that moulds had received heat damage during casting. Breakage is more intensive on thinner moulds (Cat. No. 2.1-2) than on thicker ones that are much more heat resistant (Cat. Nos 3.1-3.2).

\subsection{Conclusions}

The results of the macroscopic examinations suggest that the casting moulds from Hatvan-Strázsa-hegy are products of local, advanced metallurgy. The Cat. No. 1 mould can be interpreted as one part of a bivalve mould, which was left unfinished and never used for casting. The four dagger blade moulds can be arranged to two bivalve mould pairs ${ }^{38}$ and they were used, probably more than once. These moulds might seem simple in their design, but they offered solution for different technological problems referring to the possibility that they had been made in a professional workshop. The existence of unfinished and used moulds that can be associated with large complex objects is a further proof, that professional metallurgy was present on the Hatvan-Strázsa-hegy tell. The appearance

\footnotetext{
${ }^{35}$ Similar can be seen on smaller dagger moulds, e.g. Spišský Štvrtok (Br B1). See VladÁR 1972, 23, Tab. IV.1; BouZEK 2004, Abb. 2.1; BÁTORA 2009, Fig. 21.

${ }^{36}$ Casting moulds with multiple negatives are not unique at all in Bronze Age metallurgy. See BočKAREv-LeSKov 1980, Taf. 6.47-48, Taf. 8.72, Taf. 10.80, 83, 84, Taf. 11.90, Taf. 12.97, 102, Taf.
}

13.113, 117, Taf. 14.131; KovÁcs 1986, Abb. 3.1; JANTZEN 2008, Taf. 56.170, Taf. 59.177; SzATHMÁRI 2017, Fig. 8.3.

${ }^{37}$ E.g. the hilt mould (Cat. No. 1) showed shovel-like impact marks on its upper part.

${ }^{38}$ SCHWENZER 2004, 141-142, 172. 


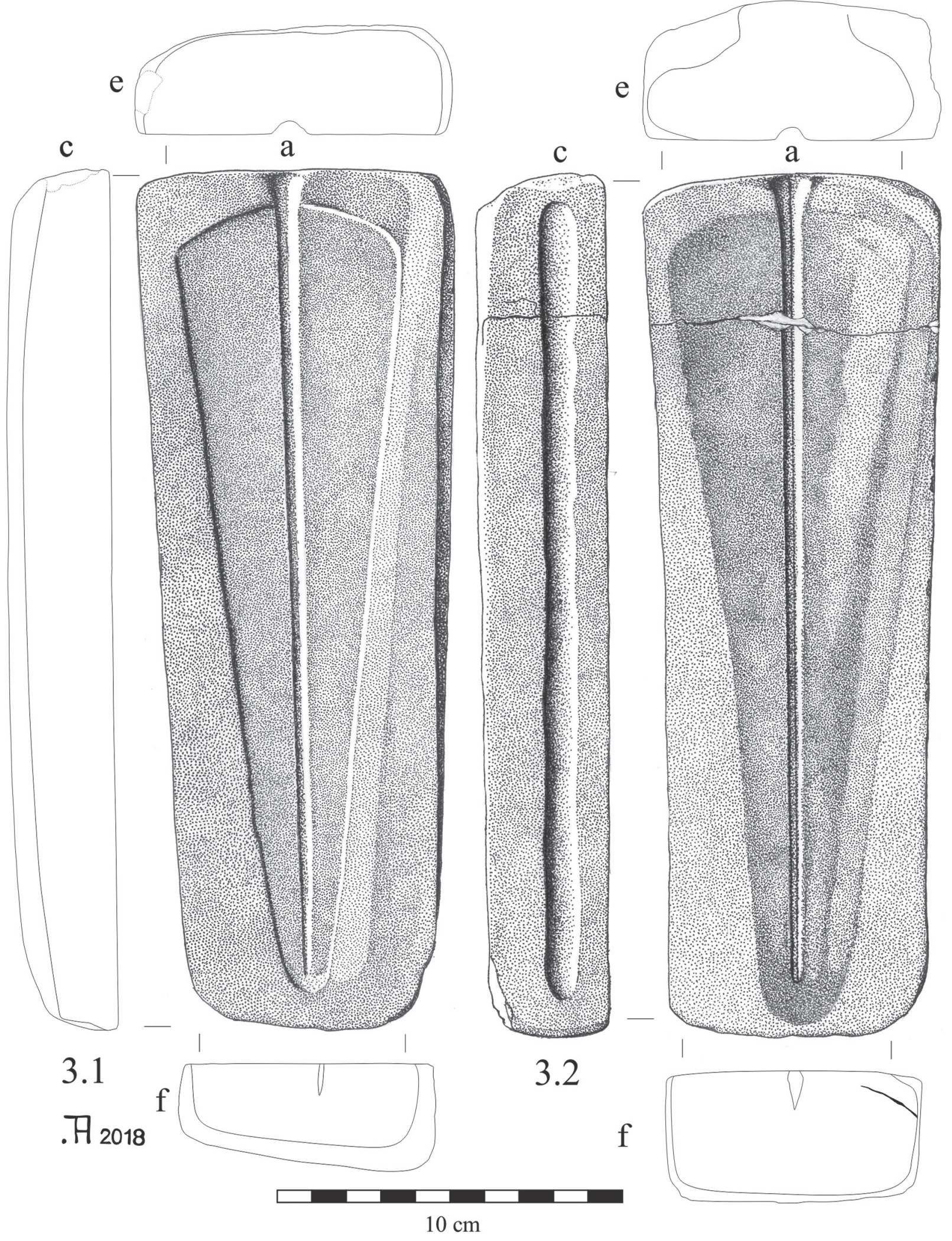

Fig. 7. Bivalve dagger mould, Pair II (Cat. Nos. 3.1-3.2) (MoD IMMH, Drawings: A. M. Tarbay) 
of moulds on sites in context with the Hatvan pottery style, are not unparalleled,$^{39}$ but they are quite rare and none of them can be associated with the manufacturing of large daggers.

\section{TYPO-CHRONOLOGY AND FUNCTION}

\subsection{Brief research history of early daggers and halberds from the territory of Hungary}

The first study on daggers and halberds from Hungary was given by J. Hampel, who identified the halberd from the Ipoly river bed and pointed out its Western European counterparts. He also provided five typological classes for Bronze Age daggers. ${ }^{40}$ A typo-chronological evaluation of the halberd of Szőny was also given by Stephan Foltiny, in which he dated the object to the EBA, based on the results of the 1950 research ${ }^{41}$ After discussing the hilting technics of daggers and swords in $1930,{ }^{42}$ another seminal work has been written by Lajos Márton. He not just provided evaluation for daggers and halberds, primarily from the territory of Hungary, but he also analysed the development and manufacturing technology of these early weapons. ${ }^{43}$ The Hungarian halberds have been discussed in European context by Seán P. Ó Ríordáin in his seminal work titled as 'The Halberd in Bronze Age Europe. A study in Prehistoric Origins, Evolution, Distribution, and Chronology'. ${ }^{44}$ Dagger and weapon representation on Early and Middle Bronze Age pottery in Hungarian sites, their cultural context and significance were evaluated in detail by Tibor Kovács in $1973 .{ }^{45}$ Also new results were proposed on this topic in 1988 in connection with the find from Tószeg. ${ }^{46}$ Both halberds and daggers from Hungary have been published in Tibor Kemenczei's PBF monograph in 1988, in which these were classified under the group "Langdolch". ${ }^{47}$ In 1996, T. Kovács have published his seminal study on the halberds from the territory of Hungary, in which he had re-interpreted some specimens of T. Kemenczei's "Langdolch" group. Due to the lack of material related to local manufacturing, he interpreted them as remnants of trade and cultural connections between the Middle Danube Basin, Northern and Central Europe. ${ }^{48}$ The last halberd (or dagger) was published in 2013 from the private collection of István Kern by Gábor Ilon. ${ }^{49}$

\subsection{Daggers or halberds? Functional evaluation of the finds cast in the moulds}

Differences between daggers and halberds cannot always be determined, especially in the case of wooden hafted ones. This problem is valid for the territory of Hungary where the halberds are rare, and the triangular-shaped bladed weapons were interpreted in different ways. If we rely on T. Kemenczei's definition, they can be identified as long daggers. In contrast, T. Kovács has suggested that these objects were wooden hafted halberds. ${ }^{50}$ In the moulds from Hatvan-Strázsa-hegy triangular-shaped bladed weapons with rounded (Cat. No. 1) or slightly slant (Cat. No. 2) butt-ends could be cast. Both are emphasized with rhomboid-sectioned midribs and had a rounded tip, which is a common feature among halberds and daggers alike. They also could have a considerable length and thickness: Pair I (Length: ca. $160 \mathrm{~mm}$ ), Pair II (Length: ca. $230 \mathrm{~mm}$ ).

The differences between daggers and halberds can be determined based on the formal features (shape of the hilt, thickness and width of the midrib, asymmetry of the blade, positions and shapes of the rivets, weight) and macroscopic traces (blade-on-blade impacts etc.). The main differences between the two weapons is that in most cases the latter are more resilient heavy objects, which can withstand extreme damages, while large daggers are thinner and lighter and usually show only minor damages. ${ }^{51}$ This can be well illustrated by specific finds from the

\footnotetext{
${ }^{39}$ See HAMPEL 1877, Pl. XIV.4; BALÁZs 1905, 413; BALÁZS 1906, 348-349, 1-3. ábra; Kalicz 1968, 117, 119, 162-164, Taf. LXXVI.6a-b, Taf. LXII.1-4, Taf. LXVII.18, Taf. LXIX.6, Taf. LXXIX.1-3, Taf. CI.1; MárTon 1931, 37, Abb. 13; KALICZ 1984, 200-201, Taf. VII.20a-b, 22-23; BÓNA 1992b, 49-50.

${ }^{40}$ Hampel 1886, Taf. XIX; Hampel 1895, Abb. 30; Hampel 1896, 63-70, 108-109, Abb. 23; MÁrTOn 1931, Abb. 3.1a-b; KovÁcs 1996, 90.

${ }^{41}$ Foltiny 1955, 60, Taf. 34.1.
}

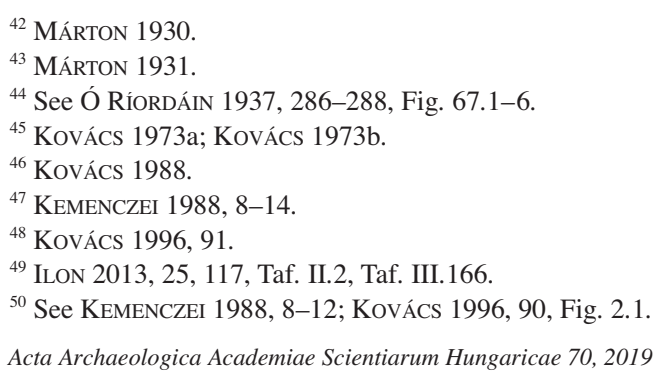




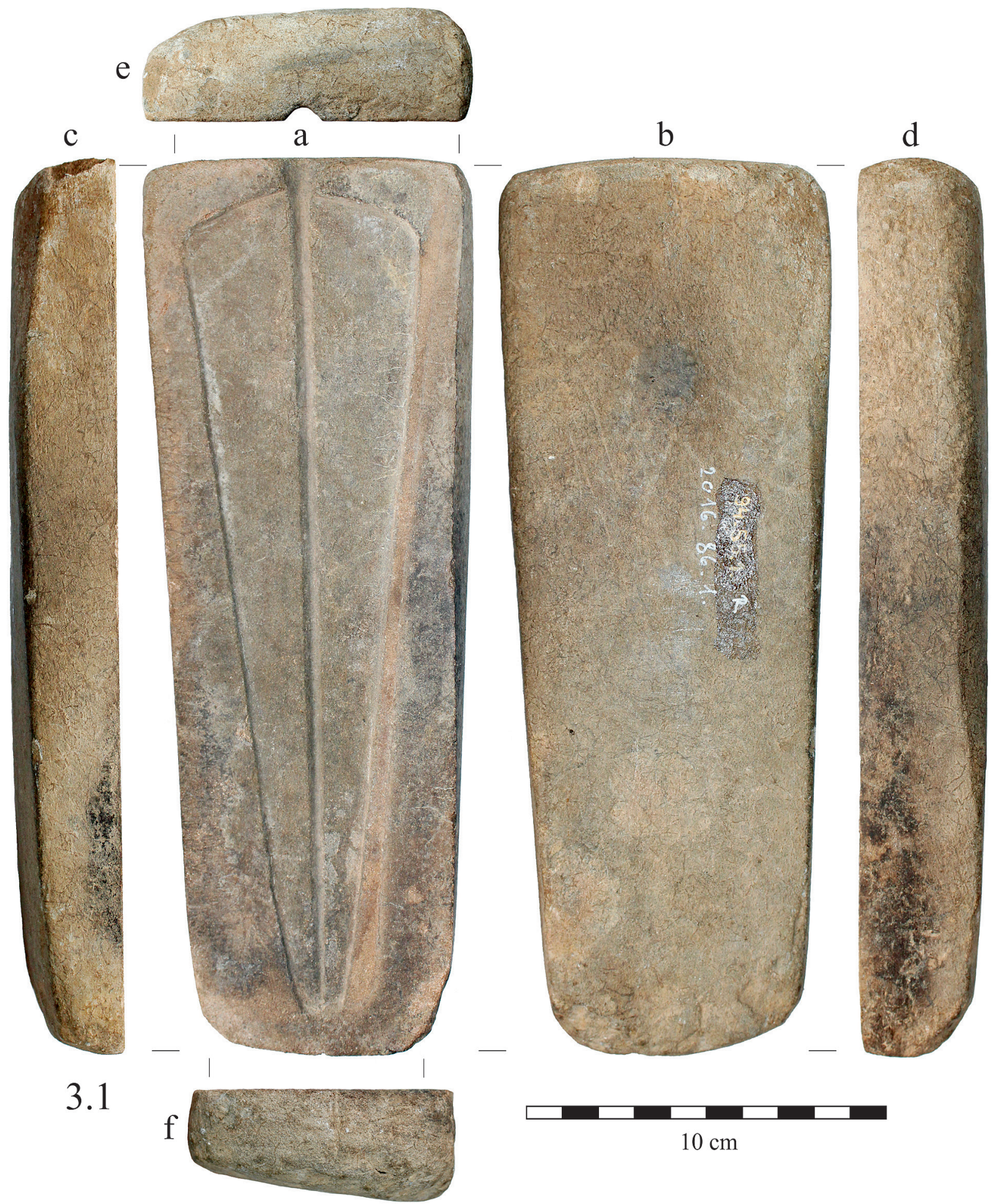

Fig. 8. Cat. No. 3.1 dagger mould (MoD IMMH, Photos: J. G. Tarbay) 


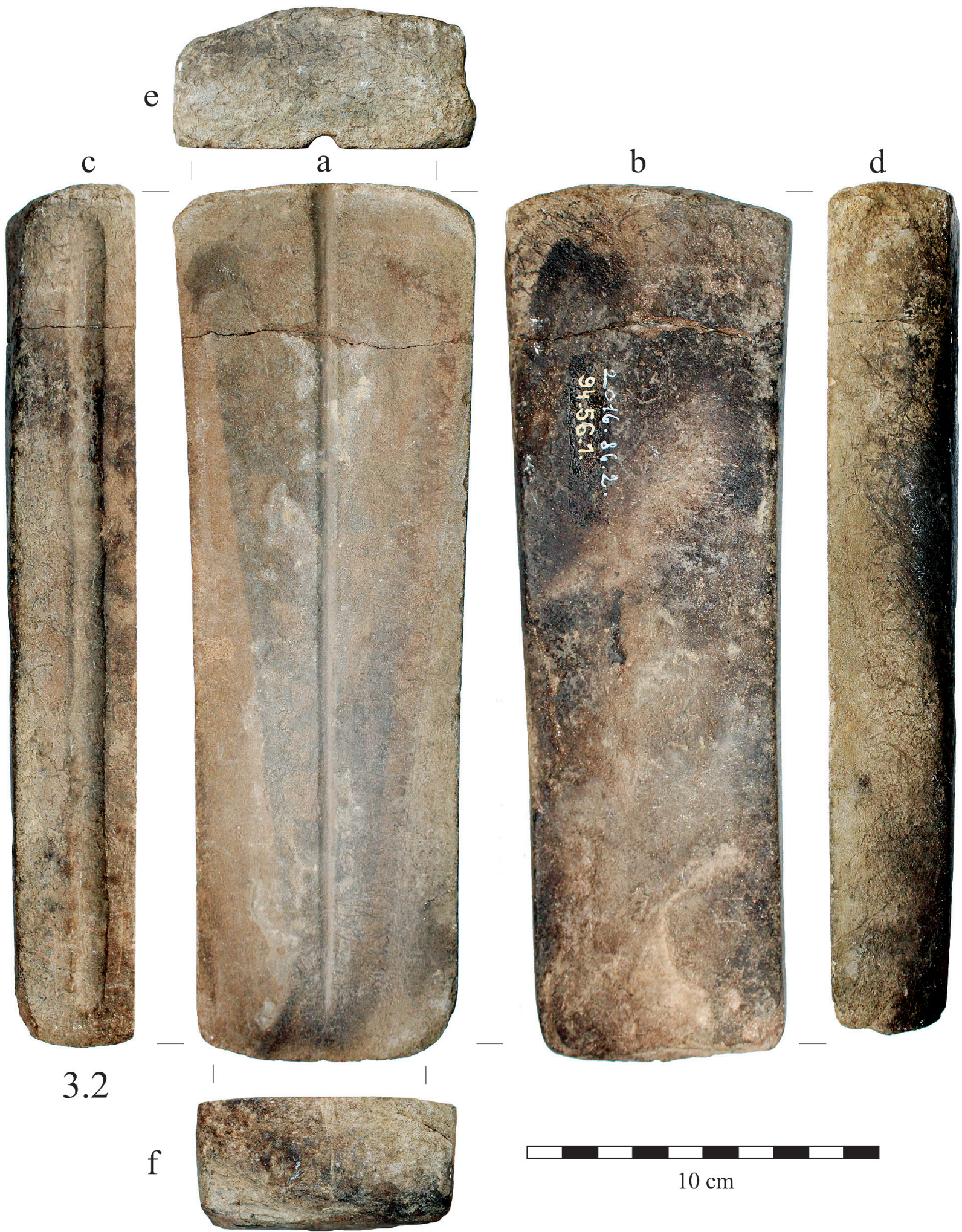

Fig. 9. Cat. No. 3.2 dagger mould (MoD IMMH, Photos: J. G. Tarbay) 

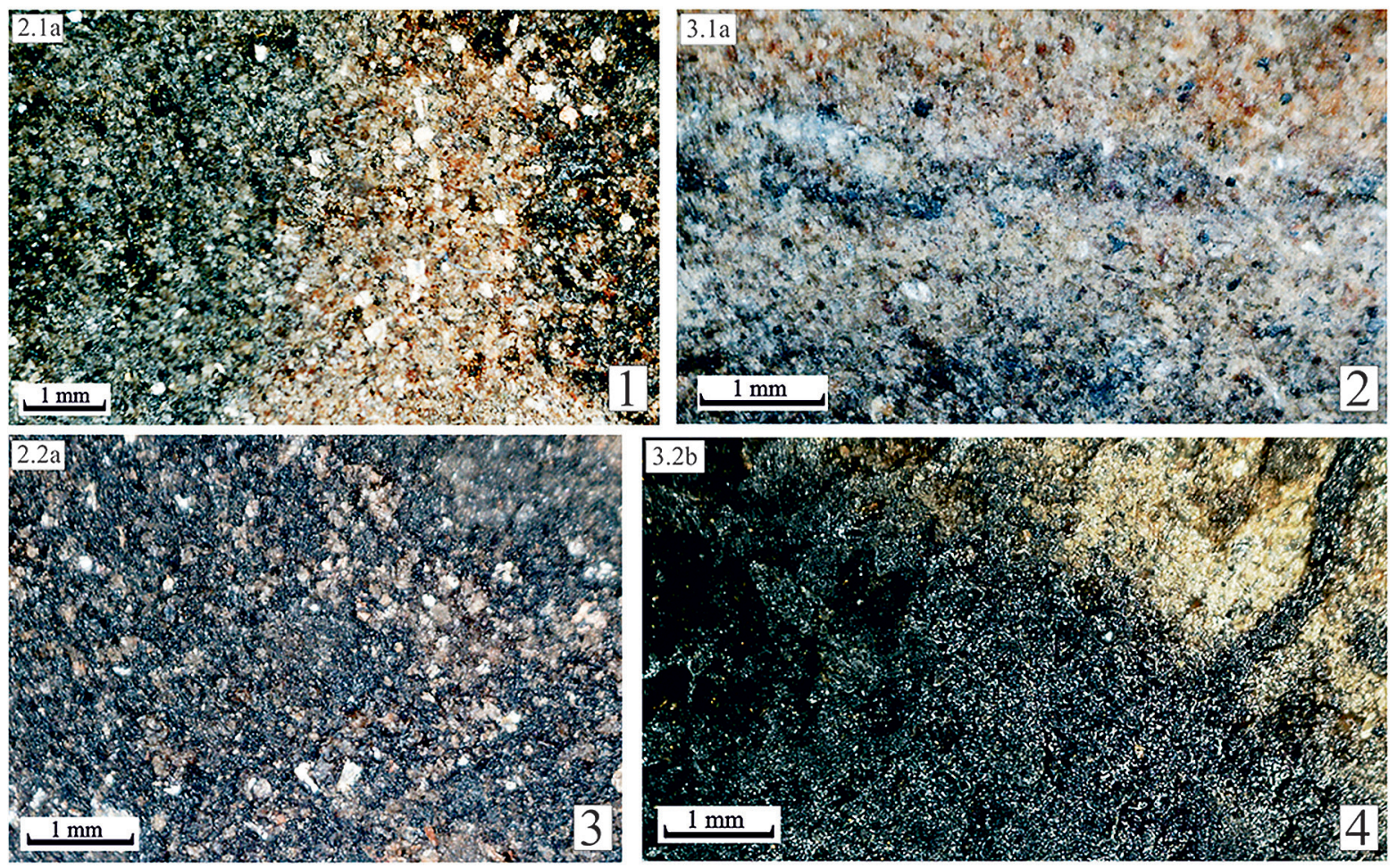

Fig. 10. Burnt surfaces on the moulds from Hatvan-Stárzsa-hegy (Cat. Nos 2.1-3.2) (MoD IMMH, Micrographs: J. G. Tarbay)

Carpathian Basin, functional identification of which is beyond dispute. The first example is an unprovenanced object, interpreted as a halberd (Appendix, Cat. No. 6, Fig. 14.6) by T. Kovács, based on its parallel finds. ${ }^{52}$ It is a robust weapon with a thick midrib, weighing almost a half a kilogram. Its edges are carefully hammered and completely sharpened (Fig. 15.3). This halberd could have been used a lot. The rivet holes of the objects show abrasion and also different types of micro-damages are visible along its cutting edge, including old worn impacts (Fig. 15.3, 5) and damages made perhaps by blade-on-blade $\operatorname{contact}^{53}$ and U-notching ${ }^{54}$ (Fig. 15.6-7). The other halberd originates from the Ipoly region (Appendix, Cat. No. 7, Fig. 14.7), but has clear typological connections to the regions of the Oder and Elbe Rivers. ${ }^{55}$ In this case, the blade was cast along with the metal hilt and decorated with 6 pseudo-rivets. It is thin and equipped with a wide and flat midrib. Compared to the unprovanenced piece, the tip of the object is rounded. Regardless of its elegant design and the minor casting defects that can be observed on this object (Fig. 16.1-3), this halberd was also likely used. Along its edges many micro-damages (blade-on-blade impact, U-shaped damages) can be seen, some of them are worn and flattened (Fig. 16.6-9). The object's tip even shows micro-creasing due to a possible stabbing damage ${ }^{56}$ (Fig. 16.5). For comparison one triangular-shaped dagger was also analysed by macroscopic observations (Appendix, Catalogue, Nos 9-10). It is an unprovenanced long, triangular-shaped dagger (Cat. No. 9, Fig. 17.9), which can be interpreted as close parallel of the Hatvan-Strázsa-hegy moulds regarding its shape, manufacturing technology and dimensions. This object is much lighter than the halberds, its blade is thinner and the hammering along the edges is less visible. According to the rivet marks (Fig. 18.1) and the flattening of the conical-shaped sprue remain (Fig. 18.2) on the butt-end, the object was manufactured and ready hafted. The characteristics of this object suggest that it was not designed to withstand rough impacts. Serious micro-notches caused by blade-on-blade impacts are missing from the cutting edges, only small nicks are visible

\footnotetext{
${ }^{51}$ Gallay 1981, 124; Klieber 2006, 139.

${ }^{52}$ Meier-Arendt 1969，56; Schauer 1971，60-61; KovÁcs 1996, 90, Fig. 2.1.

${ }^{53}$ O'FlaherTY-Gilchrist-COWIE 2011, Fig. 13-14.

${ }^{54}$ O'FlaherTy-Gilchrist-Cowie 2011, 43, Fig. 4.
}

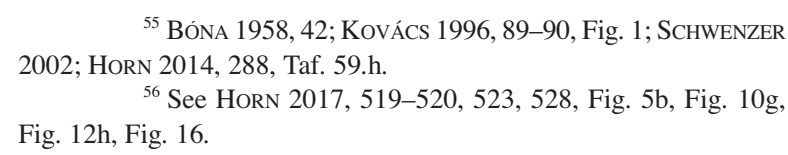

${ }^{55}$ BÓNA 1958, 42; KovÁCS 1996, 89-90, Fig. 1; SCHWENZER 2002; HORN 2014, 288, Taf. 59.h.

${ }^{56}$ See Horn 2017, 519-520, 523, 528, Fig. 5b, Fig. 10g, Fig. 12h, Fig. 16. 

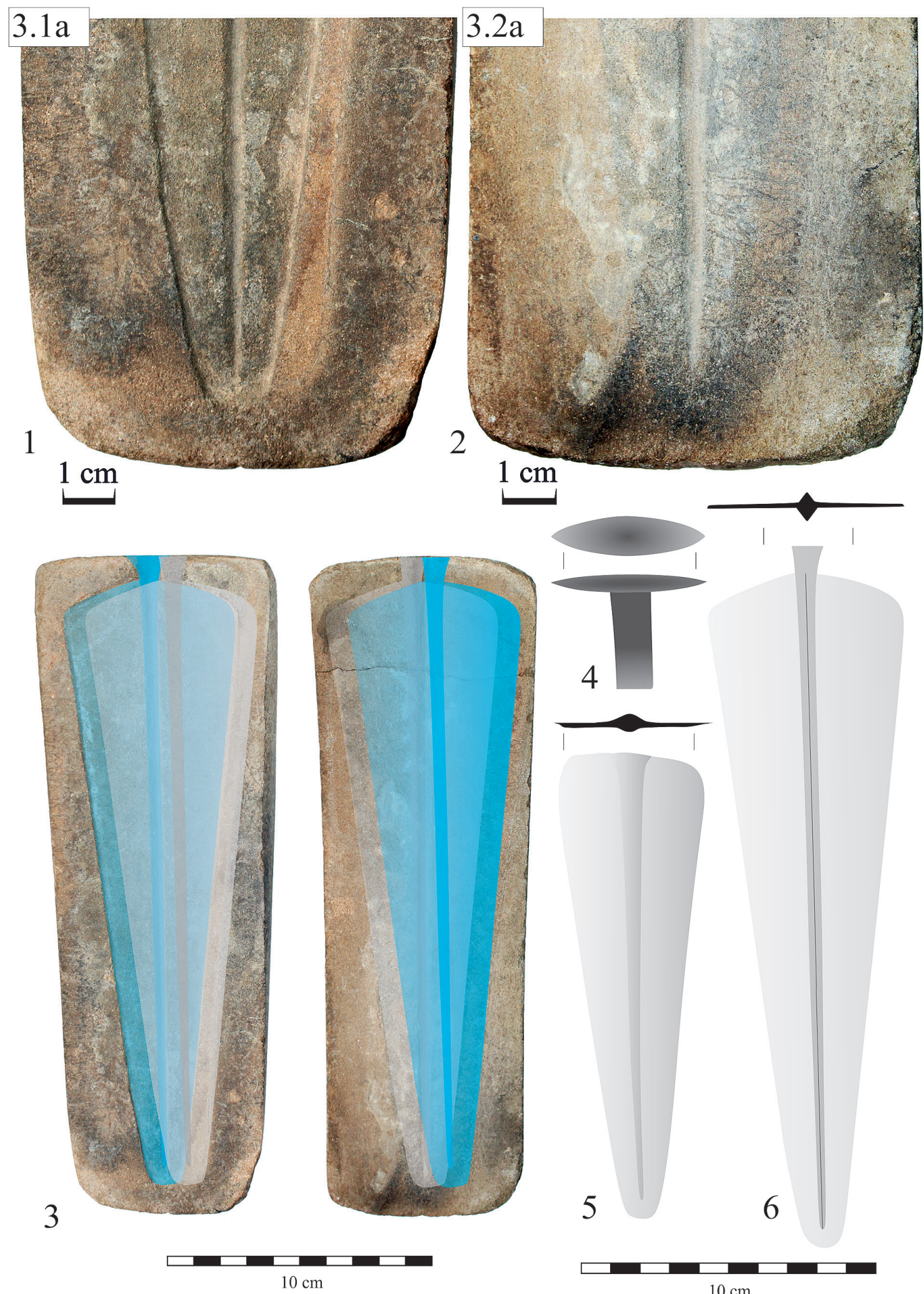

Fig. 11. 1-3: Multiple burnt imprints on Pair II; 4-6: Shape of the raw casts that could have been in the moulds (Photos\&Sketches: J. G. Tarbay) 

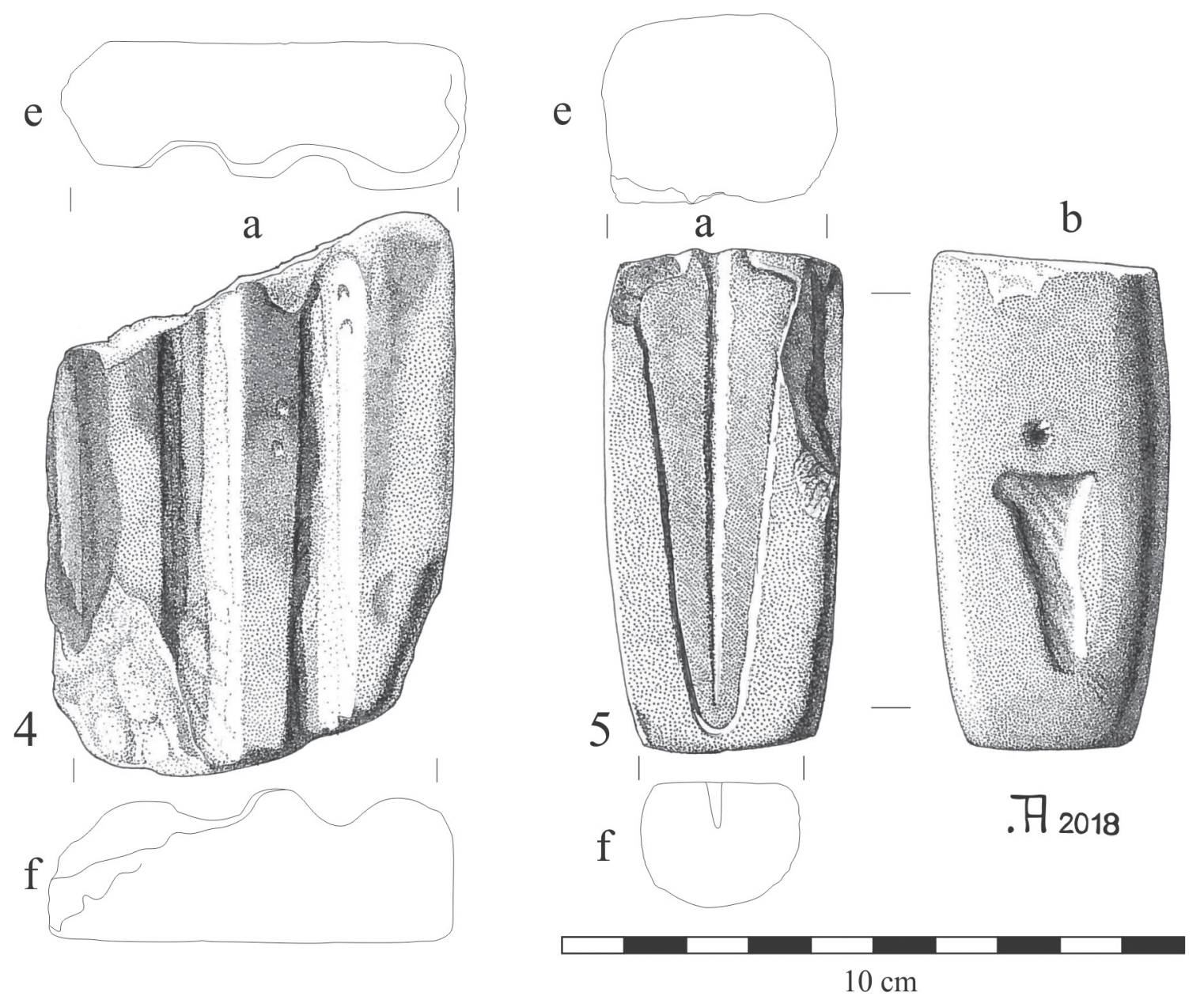

Fig. 12. Casting moulds. 4: Rod ingot casting mould from Hatvan-Strázsa-hegy (HNM); 5: Casting mould of a dagger from Maklár-Baglyos-halom (HNM, Drawings: A. M. Tarbay)

along its blade (Fig. 18.6), suggesting that this weapon was used for different purposes than the two halberds. ${ }^{57}$ Based on the differences in the design and macroscopic traces on the parallel find of the Hatvan-Strázsa-hegy moulds and the halberds, it is more likely that the objects made in the discussed moulds can be interpreted as daggers despite their relatively long length.

\subsection{Typo-chronologycal evaluation - moulds and cast parallels}

\subsection{1. (Cat. No. 1)}

The pommel mould is an unfinished product. Thus, the depth and the width of its negative cannot be considered final, which does not allow us to make fine typological comparison of the find. It seems that Stefan Schwenzer's Group V is the most similar to the object that the mould maker intended to carve. ${ }^{58}$ 

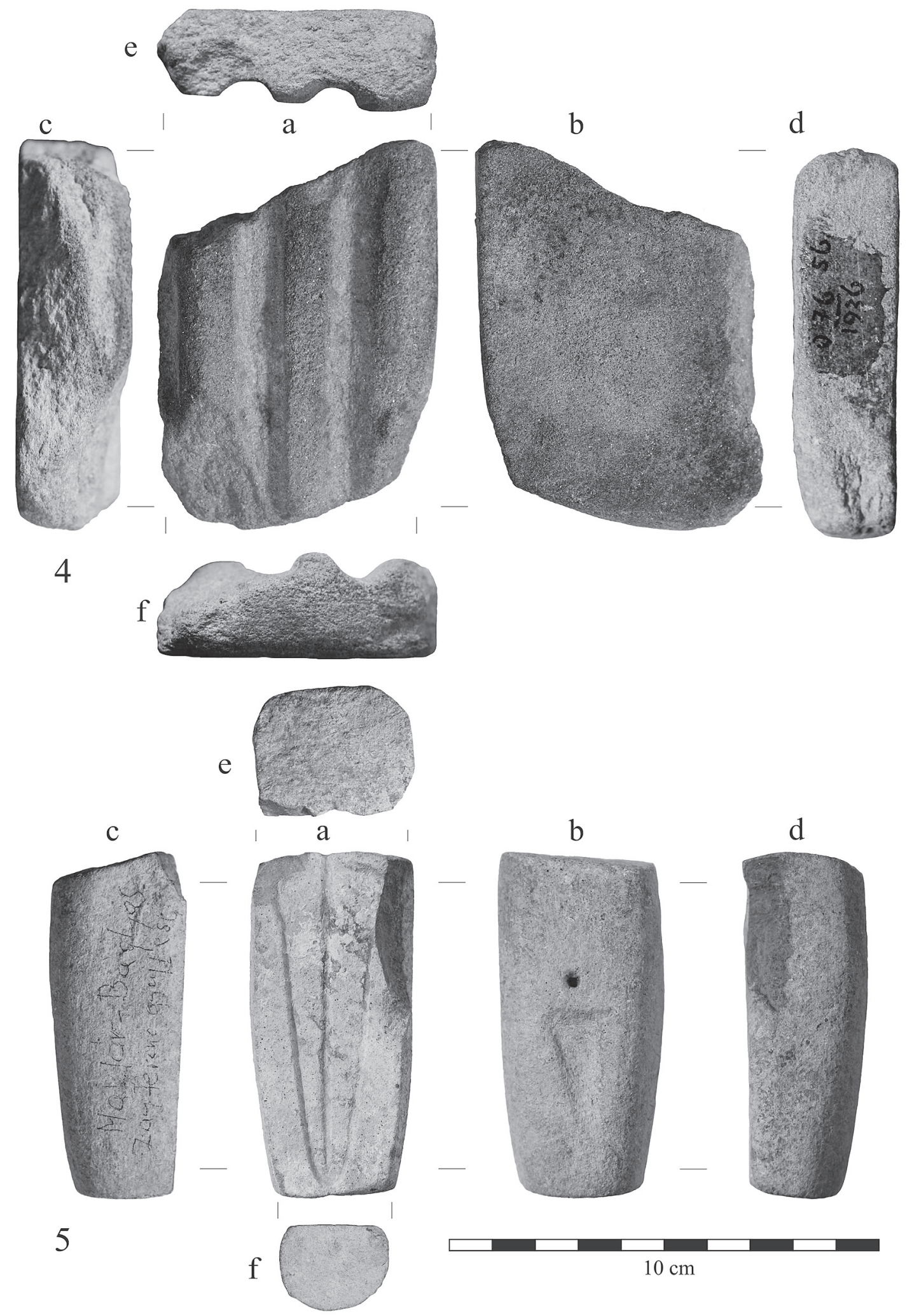

Fig. 13. Casting moulds from the collection of the HNM. 4: Rod ingot casting mould from Hatvan-Strázsa-hegy (Cat. No. 4); 5: Casting mould of a dagger from Maklár-Baglyos-halom (Cat. No. 5) (Photos: J. G. Tarbay) 


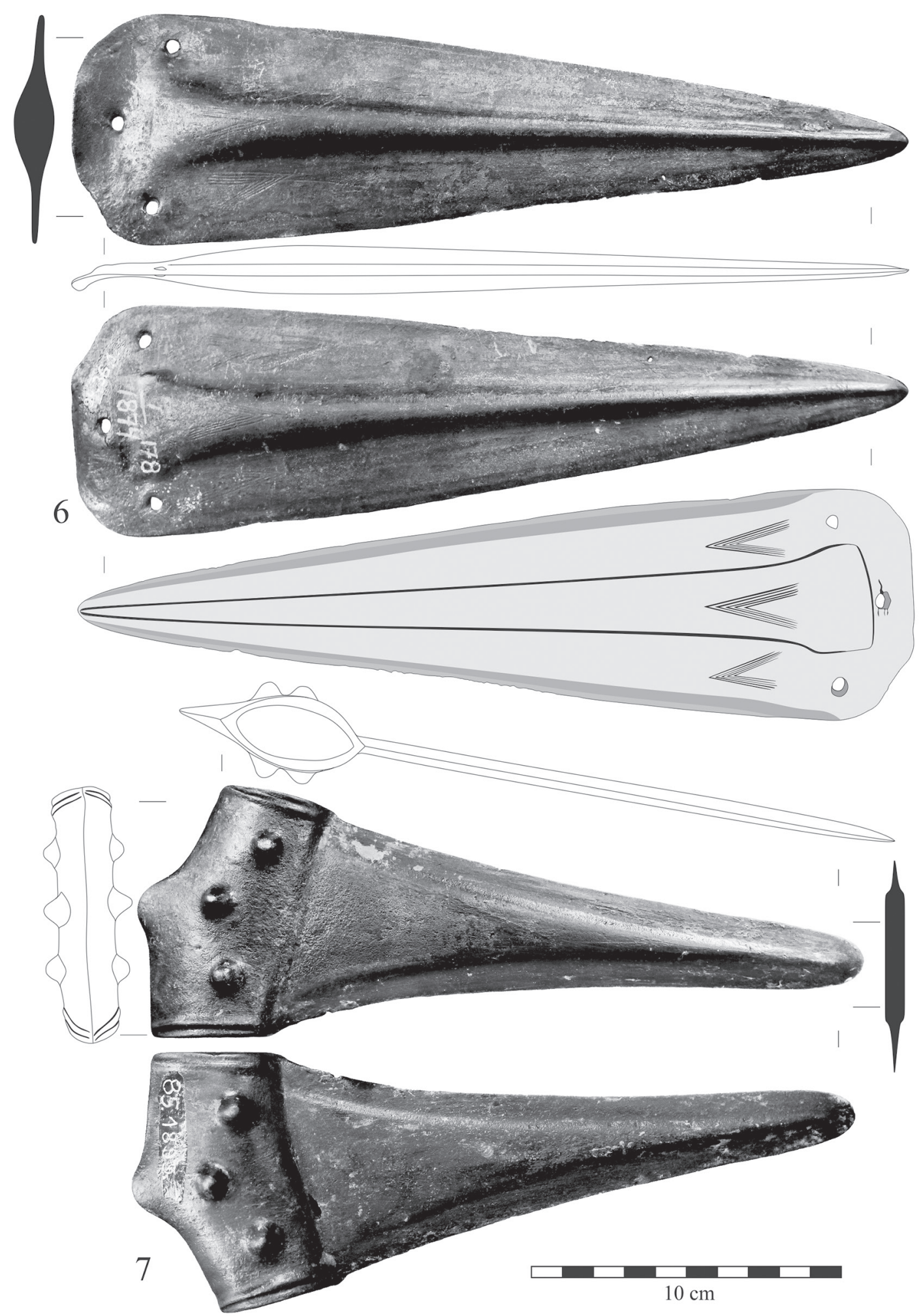

Fig. 14. Halberds from the collection of the HNM. 6: Unprovenanced halberd (Cat. No. 6); 7: Halberd from the Ipoly region (Cat. No. 7) (Photos\&Drawings: J. G. Tarbay) 

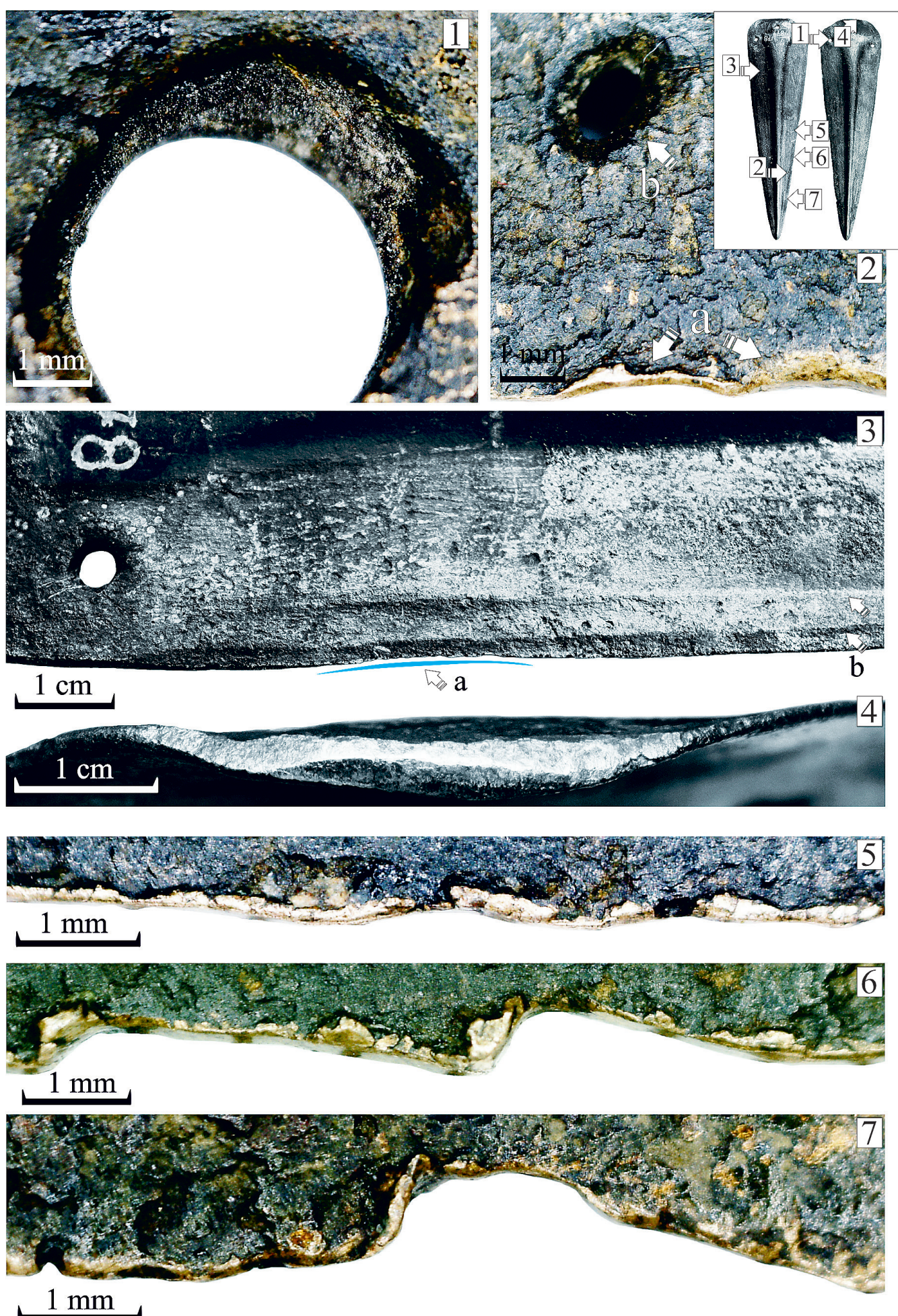

Fig. 15. Macroscopic observations on the unprovenanced halberd (Cat. No. 6) from the HNM. 1: Worn rivet holes; 2a: Micro-nicks, one of them is worn; 2b: Casting defect; 3a: Previously damaged part with multiple new micro-nicks; 3b: Hammering traces along the edges; 4: Bent and hammered butt-end; 5: Worn micro-nicks;

6: Micro-nicks probably caused by blade-on-blade impact; 7: Deep and worn micro-nicks (Photos\&Micrographs: J. G. Tarbay) 

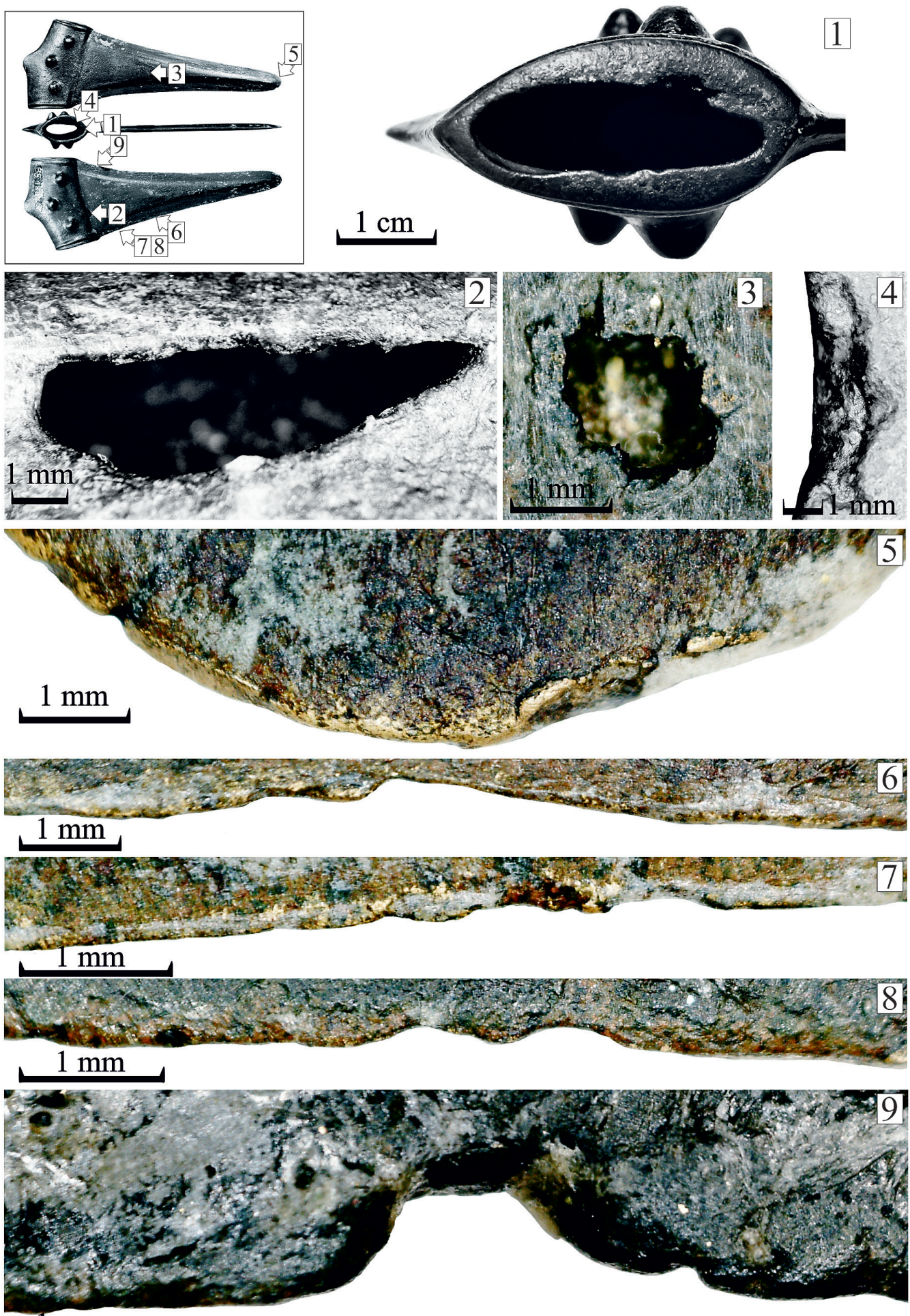

\section{$1 \mathrm{~mm}$}

Fig. 16. Macroscopic observations on the halberd from the Ipoly region (Cat. No. 7). 1: Misrun and mismatch defects (bottom view); 2. Small misrun defect; 3: Shrinkage porosity;

4: Incomplete defects in high-resolution; 5: Micro-impact damages on the tip; 6: Possible blade-on-blade damage, worn; 7-8: Worn micro-nicks; 9: Deep and worn micro-nicks (Photos\&Micrographs: J. G. Tarbay) 


\subsubsection{Dagger blade moulds (Cat. Nos 2.1-3.2)}

\subsubsection{Effect of manufacturing and use on the dagger typology}

During the typological evaluation of bladed weapons, one should take into account the technological characteristics of the objects. Daggers undergo several changes during their manufacturing and use, which means that the weapons cast in the same moulds could have completely different typological properties during particular stages of their use-life (Fig. 19). The raw cast daggers made in the moulds of Hatvan-Strázsa-hegy might have looked the same with larger dimensions as the one from Tápiószecső (Hungary, Pest County) (Appendix, Catalogue No. 8, Fig. 17.8). This object is a completely unfinished cast, with which the metalworker did nothing after removing it from the moulds. Even the conical-shaped casting sprue on the butt-end was left unbroken. On its surface, shrinkage porosity can be seen, which is so severe that it certainly has made this object dysfunctional as a weapon. Perhaps this is the reason why it was left completely unfinished. A raw cast dagger without serious defects would have undergo several manufacturing phases. After the removal of the sprue, the blade and the cutting edges have been hammered using different techniques. As a result, the cross-section of the object's blade changed. In case of the discussed daggers, their cross-section became elongated and their outline changed from asymmetric to symmetrical (Fig. 19B.2-3a). For hafting, it is necessary to modify the butt-end. This process may include the flattening of this part (Fig. 18.3, Fig. 19.3a) and the perforation of the rivet holes (Fig. 18.2) as it can be seen in the case of the unprovenanced dagger from collection of the Hungarian National Museum. Usage could also influence the shape of the blade. When a bladed object like a dagger was in use for a long period of time, it was important to maintain the sharpness of its cutting edge. The object was periodically re-sharpened, and if it was necessary completely reshaped. As a result of this process, the blades became narrower and sometimes even asymmetric. Whenever the tip was damaged or broken, the reshaping of the object also shortened the dagger's length. ${ }^{59}$ The effect of intensive use on daggers can be well-illustrated by a small dagger originating from the Hatvan-Strázsa-hegy (Appendix, Catalogue No. 10, Fig. 17A.10). One of the rivet holes show rivet imprint (Fig. 17B.1), the other is worn (Fig. 17B2). The blade of the object is extremely narrow and asymmetric, moreover its cutting edge is curved (Fig. 17A.10). On the microscopic images also traces of re-sharpening and flattened micro-nicks are visible (Fig. 17B.3-5). This object showed many signs of use and its overall technological character suggest that it was used until the very end of the object's life. During this use-life, the originally wide and long blade became smaller and narrower and perhaps completely different from the original design of the weapon (Fig. 19B.3b-4c).

\subsubsection{Parallels among moulds}

The dagger moulds from Hatvan-Strázsa-hegy are not unparalleled, what makes them special is their size which surpasses almost all known pieces from Eastern Europe. The first mould which served for casting similar objects was found in the Skočice hillfort (Czech Republic, Bohemia, Strakonice District). This syenite mould is much smaller $(90 \times 77 \times 42 \mathrm{~mm})$ than the ones from Strázsa-hegy. The common feature of these moulds is that their pouring cup was placed on the top of the butt-ends like in the case of Pair II. The difference between the Skočice and the Strázsa-hegy finds is the shape of the butt-end, which is much more rounded, and the midrib that has no contact with the sprue. The Skočice find was dated to the Rei. Br. A2-B1 by the Czech researchers. ${ }^{60}$ Second related find is a dagger mould fragment from the $50^{\text {th }}$ Grave from Matúškovo (Slovakia, Trnava Region). The dimensions of this object are roughly similar to the Pair I moulds from Strázsa-hegy. In this burial, in addition to the mould, an Únětice potterystyle cup, four tuyères and two sandstone rocks were found. ${ }^{61}$ In terms of size, the mould from Santovka/Malinovec/ Mad'arovce (Slovakia) is the best parallel of the moulds from Hatvan. The large mould fragment was made of sandstone, and on its lower half a triangular-shaped dagger with midrib can be seen. According to Jozef Bátora, the mould was found in a hut, along with potsherds belonging to the Mad'arovce and other "North Pannonian cultures". Among these finds a cup, two lids with incrustation, spoons, two grinding stones, antler objects, bird-shaped rattle and a bronze fragment can be mentioned. ${ }^{62} \mathrm{~A}$ rather small mould fragment has been found in the Otomani culture settlement from Spišský Štvrtok (Slovakia, Prešov Region). The negative of the form resembles to the Strázsa-hegy finds. It has a long midrib and also a conical-shaped pouring cup, placed on the top of the butt-end's negative. ${ }^{63}$ Moulds of the

\footnotetext{
${ }^{59}$ SCHNEIDER 2001, 113, Abb. 3.

${ }^{60}$ PoLÁČEK 1973, 140-141; MiLitKÝ 1995, 687-689, Obr. 1; BlaŽEK-ERnÉE-SMEJTEK 1998, 192-193, Taf. 38.178; NovÁK 2011, 132, No. 706, Taf. 47.706 .
}

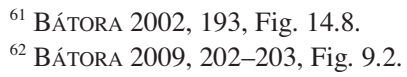


A
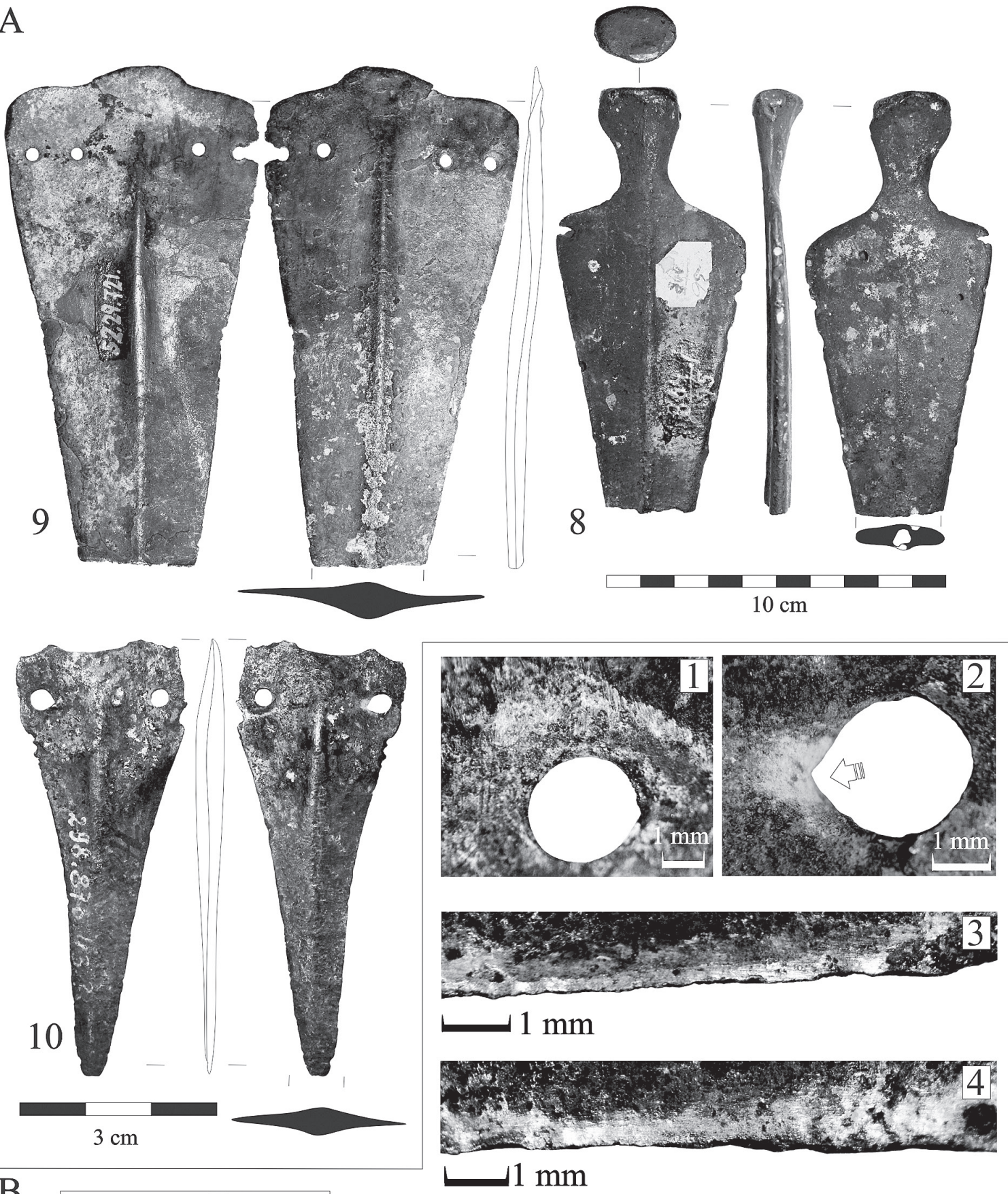

B
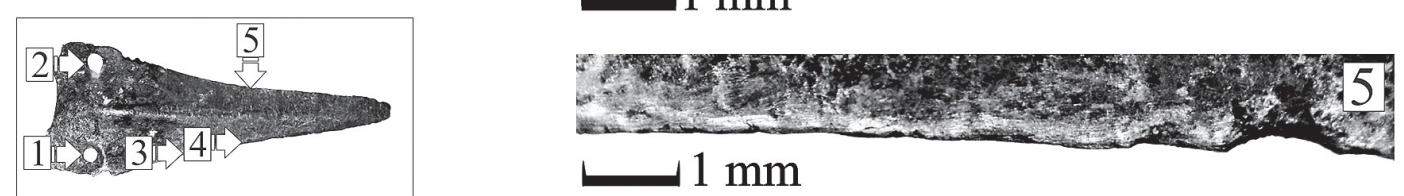

Fig. 17. A. Triangular-shaped daggers from the collection of the HNM. 8: Raw cast dagger from Tápiószecső (Cat. No. 8);

9: Unprovenanced dagger (Cat. No. 9); 10. Small dagger from Hatvan-Strázsa-hegy (Cat. No. 10).

B. Macroscopic observation on the dagger from Hatvan-Strázsa-hegy. 1: Rivet imprints; 2: Worn rivet hole; 3-5: Worn micro-nicks (Photos\&Micrographs: J. G. Tarbay) 
same type like the ones from Strázsa-hegy are rare in Hungary. I only know of one unpublished small piece from the Maklár-Baglyos-halom site (Heves County), which is a settlement that also belongs to the Hatvan pottery style. Similarly to the Strázsa-hegy moulds, this objects is also made of sandstone, which was slightly burned due to use. ${ }^{64}$ The dagger that likely was cast in this mould had a rounded butt-end along with a narrow midrib. Similarly to Pair II mould a small pouring cup was placed on the top of the butt-end. In terms of its size it was used to produce similar daggers to the Cat. No. 10 find from the Strázsa-hegy (Appendix, Catalogue No. 5, Fig. 12.5).

\subsubsection{Parallels among daggers}

As it has been already discussed, manufacturing and use affected the shape of the bronze daggers, thus finding exact parallels among the cast daggers to the Hatvan-Strázsa-hegy moulds is not an easy task. A fairly long weapon (Length: $14.5 \mathrm{~cm}$, width: $4.1 \mathrm{~cm}$ ), which was interpreted as a halberd (Ch. Horn's 7-type), was found in the cist grave from Zscheiplitz-Gleina (Germany, Saxony-Anhalt State). The object is triangular and it has a rounded butt-end and four rivet holes. Its midrib is very narrow and diamond-shaped. According to the published figures, with the exception of differing length this weapon is similar to the object that Pair I mould was capable of moulding. ${ }^{65}$ Other grave goods in the Zscheiplitz burial were a sleeve-headed pin (Hülsenkopfnadel) and a jug with round-shaped body, slightly curved neck and one handle (Form $\left.9 \mathrm{~B}_{1}\right)$. The jug was dated to the end of the $4^{\text {th }}$ Stufe and beginning of the $5^{\text {th }}$ Stufe of the "Circumharzer Gruppe" ${ }^{66}$ Harry Wüstemann determined the chronological position of this grave based on the pin (end of the Únětice pottery style - ca. Br A2). ${ }^{67}$ A long dagger (length: $20.7 \mathrm{~cm}$ ) is also known from Kolín (Czech Republic, Bohemia, Kolín District). This object is part of an uncertain hoard, which originated from a private collection. It has five rivet holes and one midrib which terminated directly below the middle rivet hole. Its butt-end is slant, which slightly distinguishes it from the Strázsa-hegy pieces. This weapon was classified as MaléŽernoseky-type by Petr Novák, who dated it to the younger phase of the Únětice culture (Rei. Br. A). ${ }^{68}$

T. Kemenczei published two unprovenanced daggers from Hungary. One is a $21.2 \mathrm{~cm}$ long blade from Tolna County (triangular-shaped long daggers with rounded hilt-plate, Variant II). These artefacts have rounded butt-ends, four rivet holes, and a long midrib. ${ }^{69}$ The other piece can be found in collection of the Hungarian National Museum. This $147.52 \mathrm{~mm}$ long, broken, triangular-shaped dagger has four rivet holes and one midrib. The midrib is connected to a conical-shaped sprue, which has been flattened by hammering (Appendix, Catalogue No. 9, Fig. 17.9, Fig. 18.1, 3) ${ }^{70}$ In addition to this unprovenanced object, two similar daggers should be mentioned. One has been published from Adony (Fejér County) (Re. Br. A1) by István Bóna. ${ }^{71}$ The other was found in TiszafüredMajoroshalom Grave B 167 (Jász-Nagykun-Szolnok County). This inhumation grave contained a $17.5 \mathrm{~cm}$ long, triangular-shaped dagger, a pin/awl and pottery from the early phase of the Füzesabony style (ca. Rei. Br A1). ${ }^{72} \mathrm{The}$ $17.5 \mathrm{~cm}$ long dagger has a thin midrib and a small extension. It has also four rivets, arranged in horizontal position. ${ }^{73}$ Lacking Carpathian parallels, T. Kovács emphasized the Aegean connections of this dagger and another one from the B 65 Grave, which he interpreted as a local redefinition of these southern weapons. ${ }^{74}$ The unique form of this dagger may also be the cause of manufacturing technology, as the butt-end and the conical-shaped sprue was flattened by hammering, like in the case of the unprovenanced dagger.

Stray find objects like the ones that were found in the Hatvan-Strázsa-hegy tell are impossible to date exactly due the destruction of their original context. Based on the related moulds and cast daggers, it seem that they have belonged to the late phase of the Hatvan-Strázsa-hegy tell and can be dated to the beginning of the Middle Bronze Age around Rei. Br A1.

${ }^{63}$ Bátora 2009, 2012, Fig. 21.
${ }^{64}$ Péterdi 2004, 508, 515, No. X/2.
${ }^{65}$ See von Brunn 1959, 75, No. 87; Wüstemann 1995, 86, Taf. 30.172, Taf. 71C; KLIEBER 2006, 177, Taf. 16.5; Horn 2014, 363 , No. 15.115 , Taf. $7 \mathrm{k}$, Taf. 107.12-14. Another difference is that the midrib terminates before the butt-end. There may be a technological reason for this if the midrib was flattened by hammering (e.g. Fig. 16.1, 3)

${ }^{66}$ HORN 2014, 27.

${ }^{67}$ WÜSTEMANN 1995, 86.

${ }^{68}$ Moucha 2007, 65, 119, Taf. 150.2; NovÁK 2011, 49, 62-63, Taf. 15.252.
${ }^{69}$ Kemenczei 1988, 10, Taf. 1.11.

${ }^{70}$ Kovács 1973b, 160, Abb. 2.1 (below); KemenczeI 1988, 10, Taf. 2.14. This object along with a dagger from Tiszafüred (B65 Grave) was associated with Aegean finds by T. Kemenczei. Aegean pieces, however, referred by Kemenczei cannot be related to these objects on a typological basis. See KeMENCZEI 1988, Taf. 2.1314; SANDARDS 1961, Pl. 18.5, Pl. 19.1.6-7.

${ }^{71}$ BónA 1975, 56, Taf. 23.10; KemenCZei 1988, 10, Anm. 5.

${ }^{72}$ Kovács 1973b, 157, 163, Abb. (1.B167); KemenczeI 1988, 10, Anm. 5.

${ }^{73}$ Kovács 1973b, Abb. 1.B167.1.

${ }^{74}$ KovÁcs 1973b, 163-164, Abb. 1.1, Abb. 2.3.

Acta Archaeologica Academiae Scientiarum Hungaricae 70, 2019 

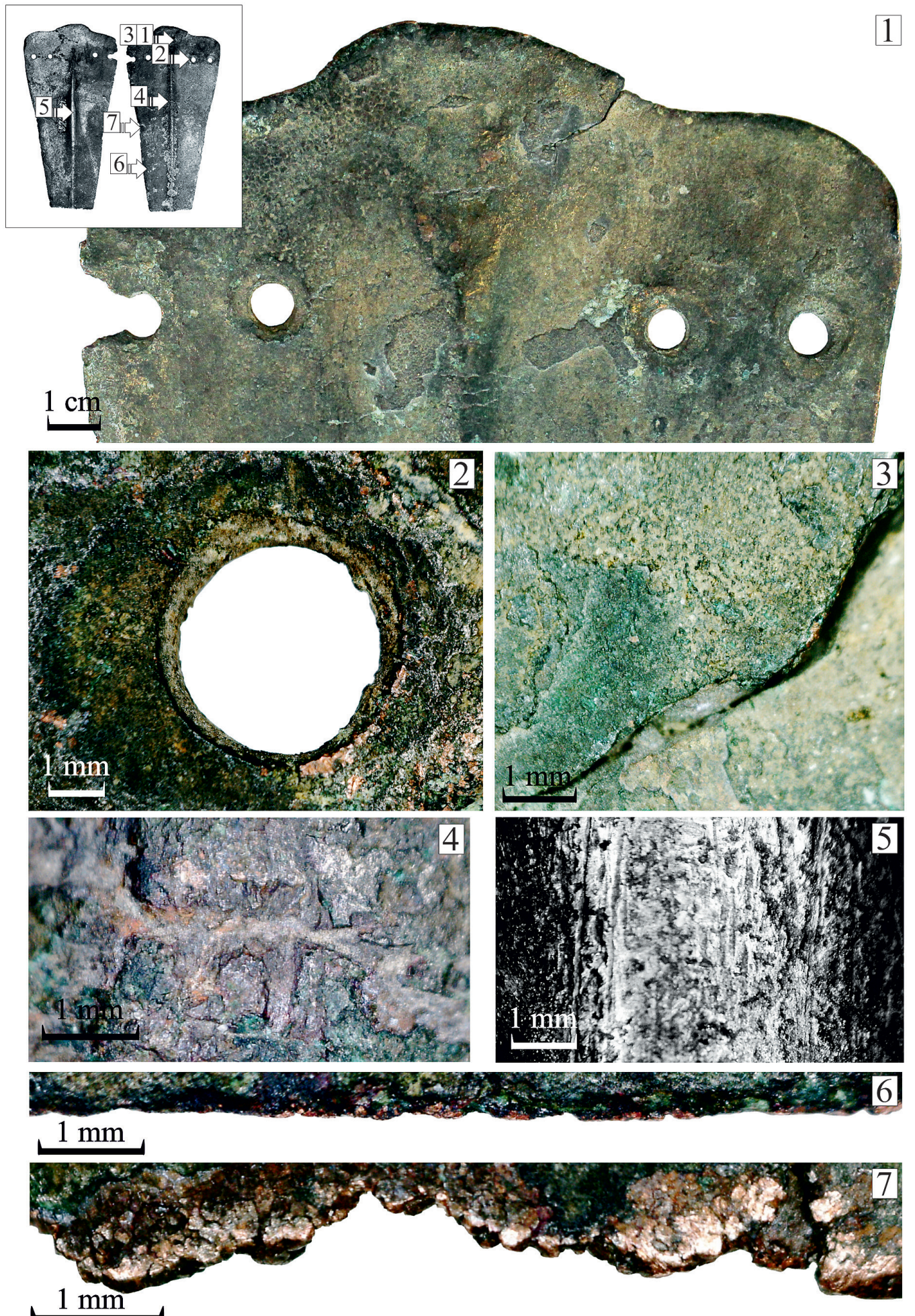

Fig. 18. Macroscopic observations on the unprovenanced triangular-shaped dagger from the HNM.

1: Casting sprue flattened by hammering, and rivet imprint around the rivet holes; 2 : Rivet imprint and wear traces on one of the rivet holes; 3: Flattened casting sprue; 4: Horizontal cracks resulted by bending; 5: Polished surface; 6: Micro-notches along the edge; 7: Recent edge damages (Photos\&Micrographs: J. G. Tarbay) 


\section{CONCLUSION AND THE LIFE-CYCLES OF MOULDS AND DAGGERS}

The daggers made in these moulds were part of weaponry, elements of which (shaft-holes axes, halberds, flat-axes, daggers, stone axes, bows and arrows) appeared during the EBA and most of them were also produced during the MBA. ${ }^{75}$ Due to their large size, it is possible that these daggers were not just simply tools or weapons, but they could have other roles as well. These objects could symbolize the masculinity or the status of their owner, as it is well-known from numerous European examples. ${ }^{76}$ The fact that these moulds were used and unfinished, and the possibility that they could have been related to the production of representative weapons suggest that an advanced local metallurgy was present in the Hatvan-Strázsa-hegy site during the Rei Br. A1; which shared cultural connections with the northern part of the Carpathian Basin, and had connections towards the territories of the Czech Republic and Eastern Germany.

The analysis of the moulds and their related finds also allowed us to reconstruct the life-cycle of these Bronze Age artefacts. In general, the manufacturing of these moulds started with the formation of an irregular sandstone block (Fig. 19.A1) using a chisel or flat-axe until it gained its rectangular shape. Further steps in the manufacturing technology included the complete polishing of the moulds using different techniques and the carving of the negatives with bladed tools. In the case of the dagger moulds from Hatvan-Strázsa-hegy, the pouring cups were carved in two different ways. The pouring cup was either a part of the negative (Pair I) or it was placed on the top of the blade negative's butt-end (Pair II). Both pouring cups were one with a midrib allowing the metal to fill the moulds' cavity much easier. Blade negatives were carved on only one of the mould halves. This practical solution helped to minimalize the negative effect of mismatch defects during casting (Fig. 19A.3). As the pommel mould (Cat. No. 1) suggests, these objects could be removed from circulation even between the different manufacturing phases. It is an unfinished object with an incomplete negative and superficially polished sides (Fig. 19A.5). The effects of the usage phase depend on the material, dimensions (shape, thickness etc.) of the moulds. The sandstone from which the moulds from Hatvan-Strázsa-hegy were made break very easily during casting. Based on the multiple blade imprints on Pair II it is possible that this mould have survived more than one casting before one half was broken into parts (Fig. 19A.4b). In the case of Pair I, the differences between the material and the dimensions of the halves raise the possibility that one of them might have been made as a replacement of a completely damaged original half. Both conclusions should be treated as technological hypothesis, based on macroscopic observations, that requires further archaeometric data for support. It can be clearly stated that these moulds were taken out from circulation in different stages of their lifespan. Four halves were used - one has left unfinished (Fig. 19A.5). The unfortunate destruction of the context do not allow us to determine exactly how these moulds were treated in the last phase of the prehistoric lifespan. They might have been simply discarded along with settlement debris to the pit. The possibility should not be excluded that they might have belonged to a hoard, which was placed intentionally and in a carefully organized way into a pit.

Based on the obtained data it was also possible to draw conclusions on the manufacturing and use of the bronze daggers, with particular attention to the typological changes that occurred during different phases of these objects' lifespan. The raw casts made from the Hatvan-Strázsa-hegy moulds had an asymmetric cross-section originally. In case of Pair II even a casting sprue was on the top of the butt-end, similarly to the raw cast from Tápiószecsö (Cat. No. 8) (Fig. 19B.2). The raw casts went through different stages of manufacturing, which included the removal and flattening of the sprue and the perforation of the rivet holes. Sharpening, cold hammering and/or annealing of the blade changed the objects' shapes completely. As a result, their cross-section became symmetric, the cutting edge thinned, the blade widened in horizontal directions (Fig. 19B.3a). The finished blades were hafted by the aid of rivets to hilts made of organic materials, metal or the combination of both (Fig. 19B.3b). As a result of use, maintenance and damages the daggers' blades changed. They became narrow, asymmetric and slightly curved. If the tip was damaged the blades could be also shortened, as it was necessary to re-shape the objects (Fig. 19B.4a-4c). Ideally, daggers have been used until they became dysfunctional like the small one from Hatvan-Strázsa-hegy (Cat. No. 10). However, this was not always the case. The raw cast dagger from Tápiószecső (Cat. No. 8) was withdrawn from circulation due to its serious casting defects. As it was a raw artefact, it did not even enter the life-cycle as it

${ }^{75}$ BÓNA 1992b, 48; KovÁcs 1996; HARding 1999, 159161; GuILAINE-ZAMMIT 2001, 160-162, 177, 184-185; FALKENSTEIN 2007, 34-39; HARDing 2007, 67; WeINBERGER 2008, 46-57.
${ }^{76}$ KovÁcs 1973a, 25-26; HAFNER 1995, 138; HARDING 2007, 57-70; FALKENSTEIN 2007, 37; WEINBERGER 2008, 55. 


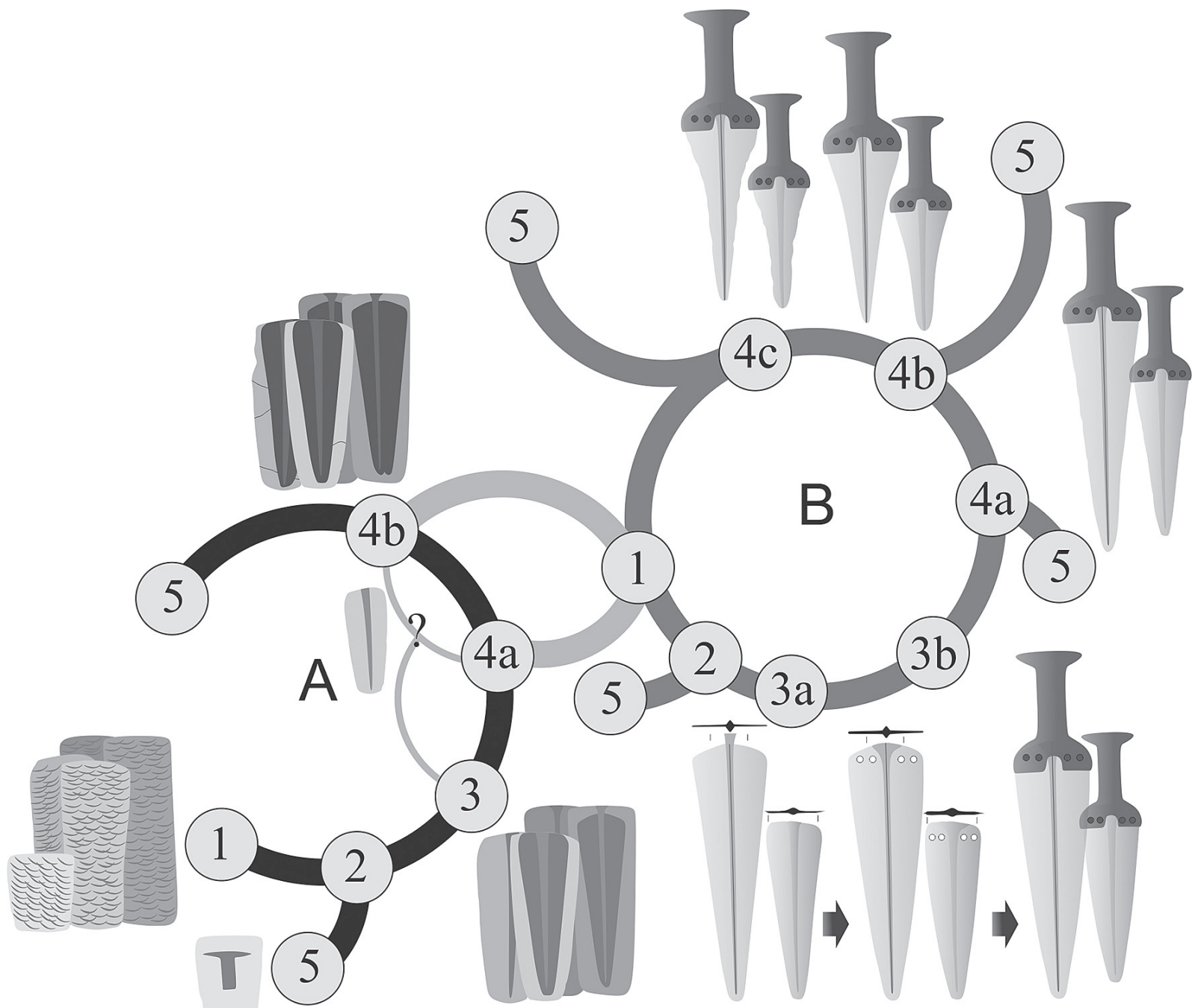

Fig. 19. The changes of moulds and daggers during their lifespan according the phenomena presented in the study.

A. Life-cycle of the moulds from Hatvan-Strázsa-hegy. 1: Carving of the stone block; 2: Polishing and carving of the negative (Cat. No. 1);

3: Finished moulds ready for casting; 4a-b: Bronze casting and the appearance of damages (burnt traces, breakage) on the moulds;

5: Final disposal in ritual deposition on graves or hoards

B. Life-cycle of cast daggers. 1: Casting; 2: Raw casts (Cat. No. 8); 3a-b: Manufacturing of the raw casts (hammering, perforation, hafting); 4: Effect of usage on daggers, e.g. appearance of nicks, narrowing of and shortening of the blade, 4a: Stage 1 (Cat. No. 9),

4b: Stage 2, 4c: Stage 3 (Cat. No. 10); 5: Final disposal or ritual deposition of the daggers in graves and hoards (Graphics: J. G. Tarbay)

has not gone through any manufacturing processes at all after being removed from the mould. In contrast the unprovenanced large dagger (Cat. No. 9) was preserved in a still usable state, and its cutting edge only showed minor damages (Fig. 19B.5). ${ }^{77}$ These objects refer to the possibility that the daggers' life-cycle could have ended in any stage, when they became part of grave goods in burials or deposited in hoards. The main question is which phase is the most typical and in what context. In order to determine this, big series should be analysed in the future using the same method that has been presented here.

\footnotetext{
${ }^{77}$ The breakage of the tip is a result of recent damage.
} 


\title{
ACKNOWLEDGEMENTS
}

Special thanks goes to András Kassa, who salvaged the finds in 1991. His discovery enriched our knowledge not just on the Hatvan-Strázsa-hegy site but also added an important piece of the Bronze Age metallurgy in the Carpathian Basin. I am grateful to the Commander of the Military History Institute and Museum of the Ministry of Defence, colonel Vilmos Kovács for the opportunity to publish the finds, and to my dear colleague Balázs Polgár for his kind help during the examination of the finds. I am also indebted to Ildikó Szathmári, Katalin T Biró and Judit Tárnoki for their advices. I would like to express gratuities to Anna Mária Tarbay for such high quality drawings of the casting moulds.

\author{
APPENDIX \\ CATALOGUE $^{78}$ \\ Casting moulds from Hatvan-Strázsa-hegy (Cat. Nos 1-3)
}

No. 1. Dagger hilt mould (MoD IMMH, Budapest; Inv. No. 2016.85.1): Unfinished sandstone mould of a dagger hilt with discshaped pommel. The object is fragmented on its upper and narrow sides due to recent damages. The narrow sides and the backside show overlapping traces of an edged tool. Tool traces that slightly run out from the negative are also visible. 1.) Dimensions of the mould: $\mathrm{L}$. $79.55 \mathrm{~mm}$, W. of the w. s. $64.33 \mathrm{~mm}-53.07 \mathrm{~mm}$, W. of the longer n. s. $24.55 \mathrm{~mm}-26.38 \mathrm{~mm}, 29.69 \mathrm{~mm}-27.03 \mathrm{~mm}$, W. of the sorter n. s. $27.16 \mathrm{~mm}-22.08 \mathrm{~mm}$, $26.70 \mathrm{~mm}-26.80 \mathrm{~mm}$ We. 237.3 g. 2.) Dimensions of the negative: L. $36.06 \mathrm{~mm}$, W. of the disc $46.81 \mathrm{~mm}, 4.84 \mathrm{~mm}$, W. of the hilt $12.66 \mathrm{~mm}$, D. of the disc $14.67 \mathrm{~mm}$, D. of the hilt $6.55 \mathrm{~mm}$. (Fig. 2, Fig. 3.1-4)

No. 2.1. Dagger blade mould (Pair I) (MoD IMMH, Budapest; Inv. No. 2016.87.1): Sandstone casting mould of a dagger. The object was "restored" by the finder from three fragments. The material of the mould is different, less rough than that of No. 2.2. The burnt traces on this mould are less visible, blackish residue can be seen on the lower part of the mould and on the backside. On the front side a dagger negative with a long rib and curved butt-end can be seen. A small sign can be observed on the lower side of the mould below the tip's negative. 1.) Dimensions of the mould: L. $170.6 \mathrm{~mm}$, W. of the w. s. $72.41-66.24 \mathrm{~mm}-38.37 \mathrm{~mm}$, W. of the convex w. s. $59.45 \mathrm{~mm}, 52.39 \mathrm{~mm}, 32.69 \mathrm{~mm}$, W. of the longer n. s. $28.99-27.65 \mathrm{~mm}-27.75 \mathrm{~mm}, 29.05 \mathrm{~mm}-28.65 \mathrm{~mm}-27.14 \mathrm{~mm}$, W. of the sorter n. s. $30.91 \mathrm{~mm}-28.61 \mathrm{~mm}, 28.84 \mathrm{~mm}, \mathrm{We}$. 540.6 g. 2.) Dimensions of the negative: L. $160.9 \mathrm{~mm}$, W. of the dagger $48.92 \mathrm{~mm}$ (curved part near to the hilt), $54.10 \mathrm{~mm}, 37.27 \mathrm{~mm}, 14.32$ mm, D. of the rib ca. $2.06 \mathrm{~mm}$, D. of the blade $1.85 \mathrm{~mm}$. (Fig. 4.2.1, Fig. 5.2.1, Fig. 10.1)

No. 2.2. Dagger blade mould (Pair I) (MoD IMMH, Budapest; Inv. No. 2016.87.2): Sandstone casting mould of a dagger. The object was "restored" by the finder from four fragments. Both the flat and the convex sides are burnt. On the flat front side, dagger-shaped burnt traces can be seen. The narrow sides of the mould are also intensively burnt and fragmented. The surface of the convex side is polished completely. Only the rib of the dagger was carved to the mould, the blade part is missing and visible only due to the burnt traces. 1.) Dimensions of the mould: L. $170.1 \mathrm{~mm}$, W. of the w. s. $64.06 \mathrm{~mm}-65.71 \mathrm{~mm}-40.63 \mathrm{~mm}$, W. of the convex w. s. $52.70 \mathrm{~mm}-49.53 \mathrm{~mm}-29.24 \mathrm{~mm}$, W. of the longer n. s. $20.67-22.02-18.39 \mathrm{~mm}, 17.05 \mathrm{~mm}-17.06 \mathrm{~mm}-17.02 \mathrm{~mm}$, W. of the sorter n. s. $21.07 \mathrm{~mm}-18.80 \mathrm{~mm}, 18.83 \mathrm{~mm}$, We. $299.7 \mathrm{~g}$ (with glue). 2.) Dimensions of the negative: L. $160.4 \mathrm{~mm}$, W. of the dagger $53.50 \mathrm{~mm}, 38.58 \mathrm{~mm}, 22.96 \mathrm{~mm}$, D. of the rib $2.70 \mathrm{~mm}$. (Fig. 3.5 , Fig. 4.2.2, Fig. 6.2.2, Fig. 10.3)

No. 3.1. Dagger blade mould (Pair II) (MoD IMMH, Budapest; Inv. No. 2016.86.1): Quadratic-shaped, sandstone mould with the negative of a dagger. The midrib of the negative is connected to the pouring cup above the butt-end of the blade negative. The cross-section of the rib is triangular-shaped. The dagger negative has slant shoulders. The casting mould shows two burnt dagger imprints, one perfectly fit to the negative, the other went beyond the negative most likely due to a mismatch defect. The tip of the blade is rounded. On the lower side of the mould a small carved sign can be seen, which served for exact fitting. Burnt traces are also visible on the narrow sides. The surface of the objects has been polished completely smooth. On one of the narrow sides slant polishing marks are also visible. Two burnt dagger imprints can be seen on the mould's front side. 1.) Dimensions of the mould: L. $250 \mathrm{~mm}$, W. of the w. s. $93.43 \mathrm{~mm}, 66.77 \mathrm{~mm}$, W. of the longer n. s. $31.04-32.42 \mathrm{~mm}$, 27.57-19.94 mm, W. of the sorter n. s. 30.19-32.08 mm, 32.09-20.29 mm, W. 1427 g. 2.) Dimensions of the negative: L. $230.3 \mathrm{~mm}$, W. of the dagger $66.73 \mathrm{~mm}, 47.28 \mathrm{~mm}, 13.72 \mathrm{~mm}$, L. of the sprue $10.76 \mathrm{~mm}$, D. of the sprue $3.91 \mathrm{~mm}$, D. of the rib $3.91 \mathrm{~mm}$, D. of the blade ca. $1.97 \mathrm{~mm}$. (Fig. 7.3.1, Fig. 8.3.1, Fig. 10.2, Fig. 11.1, 3)

${ }^{78}$ Abbreviations: L. = Length, W. = Width, We. = Weight, Th. $=$ Thickness, De. $=$ Depth, Di. $=$ Diameter, w. $\mathrm{s} .=$ wider sides, $\mathrm{n}$ s. $=$ narrow sides. 
No. 3.2. Dagger blade mould (Pair II) (MoD IMMH, Budapest; Inv. No. 2016.86.2): Quadratic-shaped, sandstone dagger blade mould. The object has been glued together from two parts. It has a long midrib connected to a pouring cup above the butt-end of the blade negative. Two dagger-shaped burnt imprints are visible on the front side and also burnt traces can be observed on the backside and on some parts of the narrow sides. The surface of the object is completely polished. On one of the narrow sides a long, irregular groove can be seen. On the lower side of the mould, a small carved sign can be seen, which served for exact fitting.1.) Dimensions of the mould: L. 25.04 mm, W. of the w. s. $87.18 \mathrm{~mm}, 74.75 \mathrm{~mm}$, W. of the longer n. s. $36.03 \mathrm{~mm}-34.67 \mathrm{~mm}, 35.22 \mathrm{~mm}-35.31 \mathrm{~mm}$, W. of the sorter n. s. $34.13-36.13 \mathrm{~mm}, 34.04-$ $35.11 \mathrm{~mm}$, We. 1644 g. 2.) Dimensions of the negative: L. $230.6 \mathrm{~mm}$, W. of the dagger $68.92 \mathrm{~mm}, 54.54 / 49.62 \mathrm{~mm}, 26.09 \mathrm{~mm}$, L. of the sprue $14.34 \mathrm{~mm}$, D. of the sprue: $4.50 \mathrm{~mm}$, D. of the rib $4.50 \mathrm{~mm}$. (Fig. 3.6, Fig. 7.3.2, Fig. 9.3.2, Fig.10.4, Fig. 11.2, 3)

Artefacts discussed within the study (Cat. Nos 4-10)

\section{No. 4. Rod ingot mould from Hatvan-Strázsa-hegy}

The object is originating from $\mathrm{F}$. Tompa's excavation. ${ }^{79}$

Rod ingot mould (HNM, Budapest; Inv. No. 1936.76.56): Small edge fragment of a larger sandstone casting mould. In this fragment, three rod ingot negatives can be seen. One of them has been burnt due to heat damage during casting, the other two show blackish traces on the upper part. The backside of the mould is completely flat and slightly blackish-grey. The burnt surface suggest that the mould has been used. 1.) Dimensions of the mould: L. $90.66 \mathrm{~mm}$, W. of the w. s. $64.34 \mathrm{~mm}, 63.29 \mathrm{~mm}, 57.35 \mathrm{~mm}$, W. of the longer n. s. $20.68 \mathrm{~mm}, 22.41 \mathrm{~mm}, 20.14 \mathrm{~mm}$, W. of the sorter n. s. $22.65 \mathrm{~mm}-21.58 \mathrm{~mm}, 20,27 \mathrm{~mm}-11.91 \mathrm{~mm}$, We. 187.8 g. 2.) Dimensions of the negative: L. of the rod (A) $74.40 \mathrm{~mm}$, L. of $\operatorname{rod}(\mathrm{B}) 66.49 \mathrm{~mm}$, L. of $\operatorname{rod}(\mathrm{C}) 40.23 \mathrm{~mm}$, W. of the $\operatorname{rod}(\mathrm{A}) 11.07 \mathrm{~mm}$, W. of the rod (B) 11.37 , W. of the rod (C, remaining part) $4.25 \mathrm{~mm}$, D. of the negative (A) $5.61 \mathrm{~mm}$, D. of negative (B) $4.83 \mathrm{~mm}$, D. of the negative (C) $7.10 \mathrm{~mm}$. (Fig. 12.4, Fig. 13.4)

\section{No. 5. Dagger casting mould from Maklár-Baglyos-halom [“Maklár-Baglyashalom”]}

The mould has been found among the uninvertoried objects of the HNM with a written note: Maklár-Baglyashalom (Maklár-Baglyoshalom $^{80}$ ) and "collected by Ferenc Zay". The artefact was also discussed by Bálint Péterdi. ${ }^{81}$ Baglyas-dülö can be found in the left bank of the Rima creek, which western part called Baglyas (or Várhegy), Bagjos-tetö. The site is entrenched and its material is characteristic for the Hatvan pottery style. $^{82}$

Dagger casting mould (HNM, Budapest; Collection of Ferenc Zay, Uninventored find from the scientific heritage of T. Kovács): Accoding to B. Péterdi's analysis it is a light, low density sandstone, which also showed burnt traces of use. ${ }^{83}$ The object is quadratic-shaped, its edges are rounded. On the front side negative, a dagger blade can be seen with a long mid-rib from top to bottom. Also a small pouring cup was added to the midrib. The edges of the mould are broken off in the front side due to a recent damage. On the bottom small sign can be seen. On the backside of the mould, small reverse triangular-shaped carving and a circular hole can be observed. 1.) Dimensions of the mould: L. 80.61 mm, W. of the w. s. $34.09 \mathrm{~mm}, 34.51 \mathrm{~mm}, 26.08 \mathrm{~mm}$, W. of the longer n. s. $24.20 \mathrm{~mm}, 23.35 \mathrm{~mm}, 18.63 \mathrm{~mm}$, W. of the sorter n. s. $19.07 \mathrm{~mm}$, $25.86 \mathrm{~mm}$, W. 140.7 g. 2.) Dimensions of front side negatives: L. $80.73 \mathrm{~mm}$, W. $27.65 \mathrm{~mm}, 7.51 \mathrm{~mm}$, L. of the sprue $3.08 \mathrm{~mm}$, D. of the sprue $1.12 \mathrm{~mm}$, D. of the rib $1.61 \mathrm{~mm}$. 3.) Dimensions of backside negatives: Triangular-shaped negative: $15.31 \times 30.43 \times 31.28 \mathrm{~mm}$, circular hole: $2.80 \times 3.40$ mm. (Fig. 12.5, Fig. 13.5)

\section{No. 6. Unprovenanced halberd (György Ráth Collection)}

The object was acquired from the collection of György Ráth in 5 January 1874. The object was first discussed by L. Márton. It has been published in several studies and monographs focused on the typo-chronology of halberds and daggers. ${ }^{84}$

Halberd [Type 7] (HNM, Budapest, Ráth Collection, Inv. nos 1874.1.178, 94.36.1): Triangular-shaped halberd with rounded shoulder, three perforated rivet holes, three V-shaped bundles of lines decoration. The midrib is emphasized and narrows towards the tip. Traces of the sprue have been hammered. The rivet holes showed abrasion. The macroscopic traces of hammering is visible along the cutting edge. The upper part of the object is slightly bent. Use-wear analysis of the artefacts showed flattened nicks, blade impacts, repaired and worn damages. L. $270.1 \mathrm{~mm}$ (end of the blade is blunt), W. $77.25 \mathrm{~mm}, 53.55 \mathrm{~mm}, 12.06 \mathrm{~mm}$, Th. of the midrib $15.29 \mathrm{~mm}, 12.03 \mathrm{~mm}, 5.12 \mathrm{~mm}$, Th. of the sprue $3.32 \mathrm{~mm}$, Th. of the blade 4.59-4.49 mm, 3.76-2.74 mm, $0.78 \mathrm{~mm}$, Di. of the rivet holes $5.36 \times 4.72 \mathrm{~mm}, 5.75 \times 5 \mathrm{~mm}(\mathrm{middle}), 6 \times 5.34 \mathrm{~mm}$, We. 495 g. Elemental composition (SAM No. 14373): Sn: 8.8, Pb: 0, As: 0.4, Sb: 0.31, Ag: 0.3, Ni: 0.14, Bi: 0.019, Au: 0, Zn: 0, Co: 0, Fe: +. ${ }^{85}$ (Fig. 14.6, Fig. 15)

${ }^{79}$ See Tompa 1937, 86, Taf. 31.23.

${ }^{80}$ Kalicz 1968, 119, No. 45.

${ }^{81}$ PÉterdi 2004, 508, 515, No. X/2.

${ }^{82}$ NovÁKI-BARÁz 2000, 9, 35, Abb. 9-10; NovÁKI et al. 2009, 44, No. 31

$$
{ }^{83} \text { PÉTERdi 2004, 508, 515, No. X/2. }
$$

${ }^{84}$ See MÁrton 1931, 20, Abb. 1.3; Ó RIORDÁIN 1937, 286-288, Fig. 67.4; Kemenczei 1988, 9, Taf. 1.8; KovÁcs 1996, 90, Anm. 8, Fig. 2.1; Klieber 2006, 178, Taf. 11.2, Taf. 17.4; Horn 2014, 291-292, No. 6.8, Taf. 7.i.

85 JUNGHANS-SANGMEISTER-SCHRÖDER 1974, 146-147, 


\section{Halberd from the Ipoly region}

According to the Inventory book of the HNM, the object is originating from the river bed of the Ipoly [Ipoly medre] (former AustroHungarian Empire, Hont County). The artefact has been acquired from Mór Wiesinger, 7 October $1893 .{ }^{86}$ It has been first published by J. Hampel, who noted that the find could have originated from the former Nyitra or Hont Counties, and was most likely unearthed during railway construction. It has been re-published in several studies focusing on the typo-chronology of halberds. ${ }^{87}$

Halberd [Type SLF] (HNM, Budapest, Inv. no. 85.1893): Halberd with long, asymmetric narrow blade equipped with a flat midrib. The surface of the blade is smooth and showed no traces of macroscopic hammer marks. The cutting edge is sharpened and several micro-nicks can be seen on it. The shaft is cast in one with the blade. A flat knob can be found on the back of the shaft. Six, conical-shaped pseudo-rivet heads can be found on the wider sides of the shaft. Emphasized collars can be seen on the shaft's rim. The two sides of the shaft do not match precisely, as the object was presumably cast in a bivalve mould and the original cast suffered mismatch defect during casting. On the blade and the shaft shrinkage porosity is visible. Two sampling traces can be observed on the artefact. The object was used. Along the cutting several worn micro-nicks, damages related to blade-on-blade contact can be seen. The tip also showed traces of impact damage. L. $234.79 \mathrm{~mm}$, W. of the socket $83.35 \mathrm{~mm}, 75.46 \mathrm{~mm}$, Di. of the socketed (upper) $38.37 \times 20.52 \mathrm{~mm}, 31.61 \times 13.66 \mathrm{~mm}$, Di. of the socket (lower): $38.57 \times 18.19 \mathrm{~mm}$, $30.14 \times 9.19 \mathrm{~mm}$, Di. of the socket to the spike $(50.37 \mathrm{~mm})$, W. of the blade $69.12 \mathrm{~mm}, 28.89 \mathrm{~mm}, 15.39 \mathrm{~mm}$, Th. of the midrib $5.96 \mathrm{~mm}$, $6.06 \mathrm{~mm}$, Th. of the blade (edge) $1.86 \mathrm{~mm}$, We. 340 g. Elemental composition (SAM No. 12772): Sn: 8.6, Pb: 0, As: 0.006, Sb: Spur, Ag: Spur, Ni: 0.03, Bi: Spur, Au: 0, Zn: 0, Co: 0, Fe: $0 .{ }^{88}$ (Fig. 14.7, Fig. 16)

\section{No. 8. Dagger from Tápiószecső-Mogyoró erdő [former Tápió-Szecső]}

The object was donated to the HNM along with an iron cross and iron sprue, in 17 October 1864 by János Szipták, a blacksmith from Tápiószecső. The object was found in the "hazelnut forest" in the surroundings of Tápiószecső. ${ }^{89}$

Dagger (HNM, Budapest; Inv. No. 1864.95): Triangular-shaped dagger with asymmetric shoulders. Emphasized midrib can be seen in the middle of the dagger. One of them continues to the pouring cup, the other terminates below the line of the shoulders. The object surface shows intensive traces of shrinkage porosity. The conical shaped casting jet has not been removed from the cast. The upper part of the object has been broken and also traces of invasive elemental composition analysis can be seen in its breakage surface. L. $125.16 \mathrm{~mm}$, L. of the blade $9.243 \mathrm{~mm}$, L. of the jet $31.38 \mathrm{~mm}$, W. of the jet $24.37 \times 16.12 \mathrm{~mm}$, W. of the blade $55.56-27.72 \mathrm{~mm}$, Th. of the midrib $7.17 \mathrm{~mm}$, Th. of the blade 3.70 mm, We. 168.4 g. (Fig. 17A.8)

\section{No. 9. Unprovenanced dagger from Hungary} the $19^{\text {th }}$ century. ${ }^{90}$

The dagger has been inventoried in 1952 and its provenance is unknown. According to T. Kemenczei it was acquired at the end of

Dagger (HNM, Budapest; Inv. No. 52.29.721): Triangular-shaped bronze dagger with narrow shoulders, midrib and four rivet holes. The midrib extends into the conical-shaped sprue which have been flattened by hammering. The four peg holes have been made by perforation and they show slight abrasion as well. Imprint of the rivet can also be observed along the holes. The surface of the dagger is corroded. The blade is slightly bent and its lower part is missing due to recent breakage. Most damages along the blade are also recent, except finer micro-notches. L. $147.59 \mathrm{~mm}$, W. $76.00 \mathrm{~mm}, 33.28 \mathrm{~mm}$, Th. of the midrib 5.78-5.56 mm, Th. of the blade: $1.41-1.31 \mathrm{~mm}$, Th. of the hammered sprue $1.87 \mathrm{~mm}$, Di. of the rivet holes $4.37 \times 4.37 \mathrm{~mm}$, We. 139 g. (Fig. 17A.9, Fig. 18)

\section{No. 10. Dagger from Hatvan-Strázsa-hegy}

The small dagger was acquired by the HNM from J. Sperlágh along with a stone axe, an obsidian flint, an oval-shaped stone tool, two spindle whorls made of potsherds and one bone pendant. ${ }^{91}$

Dagger (HNM, Budapest, Inv. no. 1876.187.5): Triangular-shaped small dagger with a midrib. The casting jet from the butt-end was broken off. The object was used intensively and over a long period of time. The rivet holes showed intensive traces of abrasion and imprint of the rivet. The blade is extremely narrow, asymmetric and slightly curved. Many micro-notches are visible along the cutting edge. L. $66.44 \mathrm{~mm}$, W. $25.72 \mathrm{~mm}, 13.15 \mathrm{~mm}$, Th. of the midrib: $4.37 \mathrm{~mm}-2.36 \mathrm{~mm}$, Th. of the blade: $1.30-0.84 \mathrm{~mm}$, Di. of the rivet holes $2.84 \times 2.84 \mathrm{~mm}$, $3.20 \times 3.77$ mm, We. 12 g. (Fig. 17A.10, B1-5)

${ }^{86}$ HNM Inv. No.1893.85.

${ }^{87}$ Hampel 1895, 30, Abb. 40; Hampel 1896, 108-109, Abb. 23; Reinecke 1899, 240, Taf. II.6a-b; MárTon 1931, 18-19, Abb. 3.1a-b; Ó RIORDÁIN 1937, 286-288, Fig. 67.8; LECHLER 1938, Fig. 29; VladÁr 1974, 54, Taf. 7.158; KemencZei 1988, 76, Taf. 48.417A; KovÁcs 1996, 89-90, Fig. 1; HoRn 2014, 288, Taf. 59.h. ${ }^{88}$ JUNGHANS-SANGMEISTER-SCHRÖDER 1968, Taf. 36, No. 12772; JuNGHANS-SANGMEISTER-SCHRÖDER 1974, 92-93, No. 12772.

${ }^{89}$ HNM Inv. No. 1864.95. On the same day a Copper Age axe and a loom weight from Tápió-Szecső have been donated to the
HNM by István Francsek. In case of the Copper Age axe, Ferenc Kubinyi noted that the objects have been found at the edge of the hazelnut forest, near to the manorial sheepcote. In the inventory book only the hazelnut forest was mentioned. HNM Inv. No. 1864.94.8-9; KUBiNYi 1864, 172, No. 766; RÓMER 1864, 162, No. 690; HAMPeL 1892, 162; PATAY 1984, 41, Taf. 9.158.

${ }^{90}$ Kovács 1973, 160, Abb. 2.1 (below); KemencZei 1988, 10, No. 14, Taf. 2.14 .

${ }^{91}$ SPeRLÁGH 1877, 60; HNM Inv. No. 1876.187.1-6. 
Armbruster 2000

BÁTORA 2002

BÁTORA 2009

BALÁZS 1905

BALÁZS 1906

BARBIERI-CAVAZUTTI 2014

BLAŽEK-ERNÉE-SMEJTEK 1998

BOČKAREV-LESKOV 1980

BOUZEK 2004

BÓNA 1958

BÓNA 1992a

BÓNA 1992b

VON BRUNN 1959

CZajlik 2012

DANI 2001

ERSFELD 1990

FALKENSTEIN 2007

O'Flaherty-GILChrist-COWIE 2011

FOLTINY 1955

FURMÁNEK-VELIAČIK-VLADÁR 1991

GALLAY 1981

GoGÂLTAN 2017

GuBA 2016

Guilaine-ZAMMIT 2001

HAFNER 1995
= B. R. ARmbruster: Goldschmiedekunst und Bronzetechnik. Studien zum Metallhandwerk der Atlantischen Bronzezeit auf der Iberischen Halbinsel. Monographies instrumentum 15. Montagnac 2000 .

$=\mathrm{J}$. BÁTORA: Contribution to the problem of "craftsmen" graves at the end of Aeneolithic and in the Early Bronze Age in Central, Western and Eastern Europe. S1A 50/2 (2002) 179-228.

= J. BÁtoRA: Metallurgy and Early Bronze Age fortified settlements in Slovakia. S1A 57/2 (2009) 195-219.

= B. BALÁzs: A Tibold-daróczi (Borsodm.) bérczúti őstelep. (Első közlemény) [The prehistoric settlement from Tibold-Darócz-Bércút, Borsod County (Part 1)]. ArchÉrt 25 (1905) 407-415.

= B. BALÁzs: A Tibold-daróczi (Borsodm.) bérczúti őstelep. (Második közlemény) [The prehistoric settlement from Tibold-Darócz-Bércút, Borsod County (Part 2)]. ArchÉrt 26 (1906) 346-354.

= M. BARBIERI-C. CAVAZUTTI: Stone moulds from Terramare (Northern Italy): Analytical approach and exeprimental reproduction. In: Proceedings of the $7^{\text {th }}$ UK Experimental Archaeological Conference, Cardiff, January 10-11 2013. EXARCH Online Journal 2014, 1-18.

= J. BLAŽEK-M. ERnÉE-L. SMEJTEK: Die bronzezeitlichen Gußformen in Nordwestböhmen. Beiträge zur Ur- und Frühgeschichte Nordwestböhmens 3. Nordböhmische Bronzefunde 3. Most 1998.

= V. S. BoČKAREV-A. M. LESKOV: Jung- und spätbronzezeitliche Gußformen im nördlichen Schwarzmeergebiet. PBF XIX/1. München 1980.

= J. BouZEK: Die Rapiere des Karpatenbeckens und die Gussform von Spišský Štvrtok. In: Einflüsse und Kontakte alteuropäischer Kulturen. Festschrift für Jozef Vladár zum 70. Geburtstag. Hrsg.: J. Bátora, V. Furmánek, L. Veliačik. Nitra 2004, 279-284.

= I. BónA: Bronzkori öntött kardíszek Borsodgesztről (Bronzezitliche gerippte Armstulpen aus Borsodgeszt). HOMÉ 2 (1958) 41-44.

= I. BÓNA: Bronzezeitliche Tell-Kulturen in Ungarn. In: Bronzezeit in Ungarn. Forschungen in TellSiedlungen an Donau und Theiss. Hrsg.: W. Meier-Arendt. Frankfurt am Main-Budapest 1992, 9-39.

= I. BÓNA: Bronzeguss und Metallbearbeitung bis zum Ende der Mittleren Bronzezeit. In: Bronzezeit in Ungarn. Forschungen in Tell-Siedlungen an Donau und Theiss. Hrsg.: W. Meier-Arendt. Frankfurt am Main-Budapest 1992, 48-65.

= W. A. vON BRUNN: Die Hortfunde der frühen Bronzezeit aus Sachsen-Anhalt, Sachsen und Thüringen. Deutsche Akademie der Wissenschaften zu Berlin, Schriften der Sektion für Vor- und Frühgeschichte 7. Berlin 1959.

= Z. CZAJLIK: A Kárpát-medence fémnyersanyag-forgalma a későbronzorban és a vaskorban [The Raw Metal Material Distribution in the Carpathian Basin during the Late Bronze Age and the Early Iron Age]. Budapest 2012.

= J. DANI: A Kárpát-medence ÉK-i részének kulturális és kronológiai kérdései a kora bronzkor időszakában - Cultural and chronological questions concerning the N-E part of the Carpathian Basin in the Early Bronze Age. In: M $\Omega$ MO $\Sigma$ I. Fiatal Őskoros Kutatók I. összejövetelének konferenciakötete. Debrecen, 1997. November 10-13. Eds: J. Dani, Zs. Hajdú, E. Gy. Nagy, L. Selmeczi. Debrecen 2001, 129-161.

= J. ERSFELD: Formen und Giessen. Restaurierung und Museumstechnik 3. Weimar 1990. (3. Aufl.) = F. Falkenstein: Gewalt und Krieg in der Bronzezeit Mitteleuropas. JBBD 47/48 (2006-2007 [2007]) 33-52.

= R. O'Flaherty-M. D. Gilchrist-T. Cowie: Ceremonial or deadly serious? New insight into the function of Irish Early Bronze Age halberds. In: Bronze Age Warfare: Manufactue and Use of Weaponry. Eds: M. Uckelmann, M. Mödlinger. BAR IntSer 2255. Oxford 2011, 39-52.

= S. Foltiny: Zur Chronologie der Bronzezeit des Karpatenbeckens. Bonn 1955.

= V. FuRMÁNEK-L. VELIAČIK-J. VLADÁR: Slovakia in the Bronze Age - Slovensko v dobe bronzovej. Bratislava 1991.

= G. GALLAY: Die kupfer- und altbronzezeitlichen Dolche und Stabdolche in Frankreich. PBF VI/5. München 1981.

= F. GogÂltan: The Bronze Age multi-layered settlements in the Carpathian Basin (cca. 25001600/1500 BC). An old catalogue and some chronological problems. Journal of Ancient History and Archaeology 4/3 (2017) 28-55.

= Sz. GuBA: A hatvani kultúra elterjedése és kutatásának állása Nógrád megyében (The spread of the Hatvan culture and the state of research in Nógrád Country). Tisicum 25 (2016) 81-90.

= J. Guilaine-J. Zammit: The Origins of War. Violence in Prehistory. Oxford 2001.

= A. HAFNER: "Vollgriffdolch und Löffelbeil": Statussymbole der Frühbronzezeit. ASchw 18 (1995) $134-141$. 
HAMPEL 1877

HAMPEL 1880

HAMPEL 1892

HAMPEL 1895

HAMPEL 1896

HARDING 1999

HARDING 2007

HENSZLMANN 1876

HORN 2014

HORN 2017

HORVÁTH 1998

ILON 2013

JANTZEN 2008
HAMPEL 1886

= J. HAMPEL: Antiquités préhistoriques de la Hongrie. Esztergom 1877.

= J. HAMPEL: A rákospalotai bronzlelet [Bronze find from Rákospalota]. ArchÉrt 14 (1880) 49-60.

= J. HAMPEL: A Bronzkor emlékei Magyarhonban. I. Rész: Képes Atlasz [Antiquities of the Bronze Age in Hungary. 1.: Illustrated Catalogue]. Budapest 1886.

= J. HAMPEL: A bronzkor emlékei Magyarhonban II. Rész: A leletek statisztikája [Antiquities of the Bronze Age in Hungary. 2.: Statistics of the Finds]. Budapest 1892.

= J. HAMPEL: Újabb tanulmányok a rézkorról [New Studies on the Copper Age]. Budapest 1895 .

= J. HAMPEL: A Bronzkor emlékei Magyarhonban III. Rész: Áttekintő Ismertetés [Antiquities of the Bronze Age in Hungary. 3.: An Overview]. Budapest 1896

= A. HARDING: Warfare: A defining characteristic of Bronze Age Europe? In: Ancient Warfare: Archaeological Perspectives. Eds: J. Carman, A. F. Harding. Sutton 1999, 157-173.

= A. HARDING: Warriors and Weapons in Bronze Age Europe. Archaeolingua Ser. minor 25. Budapest 2007.

= I. HENSZLMANN: A történelem elötti és embertani VIII. nemzetközi congressusnak Budapesten tartott ülései és kirándulásai [The Excursions and Meetings of the VIIIth International Congress of Prehistoric and Anthropological Sciences in Budapest]. ArchÉrt 10 (1876) 237-267.

$=$ СH. HorN: Studien zu den europäischen Stabdolchen. UPA 246. Bonn 2014.

$=$ CH. Horn: Combat or ritual - Wear analysis on metal halberds from the Danish Isles and the Cimbrian Peninsula. JAS Reports 14 (2017) 515-529.

= L. HoRVÁTH: Adatok a hatvani temetők, temetkezések történetéhez (Angaben zur Geschichte der Friedhöfe und Bestattungen in Hatvan). Agria 34 (1998) 91-119.

= G. ILON: Gyüjtő a velemi Szent Vid hegy lábánál. Vezető Kern István magángyüjteményében Sammler am Fuße des St. Veit Berges bei Velem. Führer in der Privatsammlung von István Kern. Köszeg 2013.

= D. JANTZEN: Quellen zur Metallverarbeitung im Nordischen Kreis der Bronzezeit. PBF XIX/2. Stuttgart 2008

JunghanS-SANGMeister-SChröDer 1968 = S. Junghans-E. SANGMeister-M. SchröDER: Kupfer und Bronze in der frühen Metallzeit Europas. Tafeln, Tabellen, Diagramme, Karten. Studien zu den Anfängen der Metallurgie 2/2. Berlin 1968.

Junghans-SANGmeISTER-SChröDer 1974 = S. JunghanS-E. SANGMEISTER-M. SchröDer: Kupfer und Bronze in der frühen Metallzeit Europas. Katalog der Analysen Nr. 10041-22000 (mit Nachuntersuchungen der Analysen NR. 1-10040). Studien zu den Anfängen der Metallurgie 2/4. Berlin 1974.

KALICZ 1968

= N. KaLICZ: Die Frühbronzezeit in Nordost-Ungarn. Abriss der Geschichte des 19.-16. Jahrhunderts v.u.Z. ArchHung 45. Budapest 1968

KALICZ 1984

= N. KALICZ: Die Hatvan-Kultur. In: Kulturen der Frühbronzezeit das Karpatenbeckens und Nordbalkans - Kulture ranog bronzanog doba Karpatskog basena i severnog Balkana. Ed. : N. Tasić. Posebna izdanja/Srpska Akademija Nauka i Umetnosti, Balkanološki Institut 22. Beograd 1984, 191-216.

KeMENCZEI 1988

= T. KeMENCZEI: Die Schwerter in Ungarn. I (Griffplatten, Griffangel- und Griffzungenschwerter). PBF IV/6. München 1988.

= J. KLIEBER: Die Stabdolche aus Österreich. ArchA 90 (2006) 139-178.

= T. KovÁcs: Representation of weapons on Bronze Age pottery. FolArch 24 (1973) 7-31.

= T. KovÁCs: Korai markolatlapos bronz tőrök a Kárpát-medencében (Frühe Bronzedolche mit Griffplatte im Karpatenbecken). ArchÉrt 100 (1973) 157-166.

KovÁcs 1986

= T. KovÁCs: Jungbronzezeitliche Gußformen und Gießerein in Ungarn. In: Siedlung, Wirtschaft und Gesellschaft während der jüngeren Bronze- und Hallstattzeit in Mitteleuropa. Internationales Symposium Potsdam, 25. bis 29. April 1983. Hrsg.: D.-W. R. Buck, B. Gramsch. VMP 20. Potsdam 1986, 189-196.

KovÁcs 1988

= T. KovÁcs: A face pot with dagger representation from Tószeg - Arcosedény Tószegről tőrábrázolással. FolArch 39 (1988) 81-92.

KovÁcs 1996

= T. KovÁCs: Halberds in Hungary and adjacent territories. In: Studien zu Metallindustrie im Karpatenbecken und den benachbarten Regionen. Festschrift für Amália Mozsolics zum 85. Geburstag. Hrsg.: T. Kovács. Budapest 1996, 89-101.

KUBINYI 1864

= F. KuBINYI: Id. Kubinyi Ferencznek1864-ik évi september hónapban Pest Megyében a Tápióvölgyén, és Heves s Szolnok törv. egyesült megyékben fekvő Nagyrév területén archaeologiai tekintetben tett kirándulásai eredményéröl szóló tudósítása [Report of Senior Ferencz Kubinyi on the Archaeological Excursions in the Tápió Valley in Pest County, and in the area of Nagyrév in the legally unified Counties of Heves and Szolnok in the Month of September, Year 1864]. ArchKözl 4 (1864) 171-173.

LECHLER 1938

MÁrTON 1930
= G. LECHLER: The beginning of the Bronze Age and the Halberd. BASPR 14 (1938) 9-54.

= L. MÁRTON: Bronzkardjaink markolatának és hüvelyének csontdíszítményei (Knochenverzierungen an Griffen und Scheiden ungarischer Bronzeschwerter und Dolchen). ArchÉrt 44 (1930) 14-27, 275-277. 
MÁRTON 1931

MEIER-ARENDT 1969

MiLITKÝ 1995

Molloy 2017

MozSOLICS 1952

Mozsolics 1984

\section{Moucha 2007}

NEŠPOROVÁ 1969

NÉMETI 1996

NovÁK 2011

NovÁKI et al. 2009

NOVÁKI-BARÁZ 2000

PATAY 1984

PÉTERDI 2004

PolÁČEK 1973

RAMA 1988

REINECKE 1899

Ó RÍORDÁIN 1937

RÓMER 1864

RÓMER 1877 a

RÓMER 1877b

SANDARS 1961

SCHAUER 1971

SCHNEIDER 2001

SCHWENZER 2002

SCHWENZER 2004

SIEDLACZEK 2011

SPERLÁGH 1877

SZABÓ 1977

SZATHMÁRI 2017

SZEVERÉNYI 2013
= L. MÁrTOn: Dolchstäbe aus Ungarn. PZ 22 (1931) 18-40.

= W. MEIER-ARENDT: Ein frühbronzezeitlicher Stabdolch in Römisch-Germanischen Museum Köln. Germania 47 (1969) 53-62.

= J. MiLitkÝ: Odlévací forma z doby bronzové ze Skočic, Ork. Strakonice (Eine Gußform aus der Bronzezeit Skočice, Bez Strakonice). AR 47 (1995/4) 687-689.

= B. P. C. Molloy: Hunting warriors: the transformation of weapons, combat practices and society during the Bronze Age in Ireland. European Journal of Archaeology 20/2 (2017) 1-37.

= A. Mozsolics: Die Ausgrabungen in Tószeg im Jahre 1948 - Раскопки в с. Тосег в 1948 г. и хронология памятников бронзового века. ActaArchHung 2 (1952) 35-69.

= A. Mozsolics: Ein Beitrag zum Metallhandwerk der ungarischen Bronzezeit. BRGK 65 (1983) 19-72.

= V. MouchA: Hortfunde der frühen Bronzezeit in Böhmen. Praha 2007.

$=$ T. NEŠPOROVÁ: K problematike Hatvanskej kultúry na južnom Slovensku (Zur Problematik der Hatvan-Kultur in der Südslowakei). S1A 17/2 (1969) 369-402.

= G. NÉMETI: Hatvan lakói a honfoglalás előtt [The Inhabitants of Hatvan before the Hungarian Conquest]. Hatvani füzetek, Új f. 1.: Dolgozatok Hatvan múltjából. Hatvan 1996.

= P. NovÁK: Die Dolche in Tschechien. PBF VI/13. Stuttgart 2011.

= Gy. NovÁKI-Cs. BARÁZ-J. Dénes-I. Feld-S. SÁRKözy: Heves megye várai az öskortól a kuruc korig [Castles of County Heves in the Period between Prehistory and the Kuruc Era]. Magyarország várainak topográfiája 2. Budapest-Eger 2009.

= Gy. NovÁKI-Cs. BARÁZ: Ôskori és középkori erődített telepek, várak Heves megye Mátrán kívüli területén (Befestigte urzeitliche und mittelalterliche Siedlungen, Burgen im Komitat Heves, außerhalb des Mátragebirges). Agria 2000, 5-46.

= P. PATAY: Kupferzeitliche Meißel, Beile und Äxte in Ungarn. PBF IX/15. München 1984.

= B. PÉTERDI: Bronzkori és vaskori öntőformák petrográfiai vizsgálata - Petrographic analysis of Bronze Age and Iron Age casting moulds. In: Halottkultusz és temetkezés. MSMO $\Sigma$ III. Öskoros kutatók III. összejövetelének konferenciakötete, Szombathely-Bozsok, 2002. október 7-9. Ed.: G. Ilon. Szombathely 2004, 487-525.

= J. PolÁČEK: Skočice, o. Strakonice. BZO 1970 [1973], 140-141.

= J. P. RAMA: Le Bronze d'Art et ses techniques. Paris 1988.

= P. REINECKE: Tanulmányok a magyarországi bronzkor chronologiájáról (Első közlemény) [Studies on the chronology of the Hungarian Bronze Age (First paper)]. ArchÉrt 19 (1899) 225-251.

= S. P. Ó RíordáIn: The Halberd in Bronze Age Europe. A study in prehistoric origins, evolution, distribution, and chronology. AAel 86 (1937) 195-321.

= F. RÓMER: Magyar régészeti krónika [Hungarian archaeological chronicle]. ArchKözl 4 (1864) $158-173$.

= F. F. Rómer: Excursion à Valkó et à Hatvan. In: Congrès international d'Anthropologie et d'Archéologie Préhistoriques. Compte-Rendu de la huitème session à Budapest, 1876. Ed.: F. F. Rómer. Budapest 1877, 214-218.

= F. F. RóMER: Galgavölgye östörténelmi szempontból [The Galga Valley from the Point of View of Prehistory]. Gödöllő és Vidéke Történelmi és Régészeti Muzeum-Egyletének Jelentése 1 (1877) 49-61.

= N. K. SANDARS: The first Aegean swords and their ancestry. AJA 65/1 (1961) 17-29.

= P. SCHAUER: Die Schwerter in Süddeutschland, Österreich und der Schweiz I. (Griffplatten-, Griffangel- und Griffzungenschwerter). PBF IV/2. München 1971.

$=$ E. SCHNEIDER: Fertigprodukthandel in der süddeutschen Bronzezeit. Abhandlungen der Naturhistorischen Gesellschaft Nürnberg 44 (2001) 109-118.

= S. SCHWENZER: Zur Frage der Datierung der Melzer Stabdolche. PZ 77 (2002) 76-83.

= S. SCHWENZER: Frühbronzezeitliche Vollgriffdolche. Typologische, chronologische und technische Studien auf der Grundlage einer Materialaufnahme von Hans-Jürgen Hundt. Kataloge Vor- und Frühgeschichtlicher Altertümer 36. Mainz 2004.

= M. SiedlaczeK: Der experimentelle Nachguss von bronzezeitlichen Schwertern. Experimentelle Archäologie in Europa 10 (2011) 109-119.

= J. SPERLÁGH: A hatvani ásatásokról [On the Hatvan excavations]. In: RómER 1877b, 58-60.

= J. Gy. SzABó: Hatvan-Strázsahegy (Heves m.). RégFüz 1/30 (1977) 7.

= I. SzATHMÁRI: On the metallurgy of the Füzesabony culture bronze finds and casting moulds from the Füzesabony Bronze Age tell settlement (A füzesabony kultúra fémművességéről. Bronzleletek, öntőminták a füzesabonyi bronzkori tell telepről). ComArchHung 2017, 51-79.

= V. SzEVERÉNYI: Bronzkori "háztüznéző": szándékos házégetés és anyagi metaforák a Kárpátmedence kora és középső bronzkorában (Deliberate house-burning and material metaphors in the Eary and Middle Bronze Age of the Carpathian Basin). In: M $\Omega \mathrm{MO} \Sigma$ VII. Őskoros Kutatók VII. 
TARBAY 2015

TOMPA 1935

TOMPA 1937

VLADÁR 1972

VLADÁR 1974

WEINBERGER 2008

WÜSTEMANN 1995
Összejövetele 2011. március 16-18. Százhalombatta, Matrica Múzeum. Eds: A. Anders, G. Kalla, V. Kiss, G. Kulcsár, G. V. Szabó. = Ösrégészeti Levelek 13 (2011) [2013] 215-232.

$=\mathrm{J}$. G. TARBAY: A new Late Bronze Age warrior equipment from East Central Europe. ArchÉrt 140 (2015) 29-70.

= F. TomPA: Bronzkori lakótelep Hatvanban (Eine bronzezeitliche Siedlung in Hatvan). ArchÉrt 48 (1935) 16-34, 241-242.

= F. TOMPA: 25 Jahre Urgeschichtsforschung in Ungarn 1912-1936. BRGK 24/25 (1934-1935 [1937]) $27-127$.

= J. VLADÁR: Predbežná správa o systematicom výskume opevneného sídliska otomanskej kultúry v Spišskom Štvrtku (Vorbericht über die systematische Ausgrabung der befestigten Siedlung der Otomani-Kultur in Spišský Štvrtok). AR 24 (1972) 18-25.

= J. VLADÁR: Die Dolche in der Slowakei. PBF VI/3. München 1974.

$=\mathrm{S}$. WeINBERGER: Warfare in the Austrian Weinviertel during the Early Bronze Age. MPK 65. Wien 2008.

= H.WÜSTEMANN: Die Dolche und Stabdolche in Ostdeutschland. PBF VI/8. Stuttgart 1974.

Open Access. This is an open-access article distributed under the terms of the Creative Commons Attribution 4.0 International License (https://creativecommons.org/licenses/ by/4.0), which permits unrestricted use, distribution, and reproduction in any medium, provided the original author and source are credited, a link to the CC License is provided, and changes - if any - are indicated. (SID_1) 
